Article

\title{
Assessing Nitrogen Cycling in Corncob Biochar Amended Soil Columns for Application in Agricultural Treatment Systems
}

\author{
Joseph R. Sanford *(i) and Rebecca A. Larson 1 \\ Department of Biological Systems Engineering, University of Wisconsin-Madison, 460 Henry Mall, \\ Madison, WI 53706, USA; rebecca.larson@wisc.edu \\ * Correspondence: jrsanford@wisc.edu
}

Received: 3 June 2020; Accepted: 6 July 2020; Published: 8 July 2020

\begin{abstract}
Biochar soil amendment to agricultural systems can reduce nitrogen $(\mathrm{N})$ leaching; however, application to agricultural nitrogen treatment systems has not been extensively explored. The objective of this study was to assess the impact on $\mathrm{N}$ leaching in soils receiving repeated $\mathrm{N}$ applications which may be observed in agricultural treatment systems. In this study, $400{ }^{\circ} \mathrm{C}, 700{ }^{\circ} \mathrm{C}$, and oxidized $700{ }^{\circ} \mathrm{C}$ corncob biochar was amended to sandy loam soil columns at $5 \%(w t / w t)$ to assess the impacts to $\mathrm{N}$ cycling following repeated synthetic $\mathrm{N}$ applications. Columns received weekly applications of either organic $\mathrm{N}(\mathrm{ORG}-\mathrm{N})$, ammonium $\left(\mathrm{NH}_{4}{ }^{+}-\mathrm{N}\right)$, or nitrate $\left(\mathrm{NO}_{3}{ }^{-}-\mathrm{N}\right)$ and the $\mathrm{N}$ effluent, gaseous emissions, and soil $\mathrm{N}$ retention was measured. Biochar produced at $400{ }^{\circ} \mathrm{C}$ significantly reduced $\mathrm{N}$ leaching compared to control columns by $19 \%$ and $15 \%$ for ORG-N and $\mathrm{NH}_{4}{ }^{+}-\mathrm{N}$, respectively, with application concentrations similar to silage bunker runoff. For $\mathrm{NO}_{3}{ }^{-}-\mathrm{N}$ applications, $700{ }^{\circ} \mathrm{C}$ biochar significantly reduced leaching by $25 \%$ compared to the controls. The primary mechanism reducing $\mathrm{N}$ effluent for biochar amended columns was enhanced soil retention of ORG-N and $\mathrm{NO}_{3}{ }^{-}-\mathrm{N}$. Biochar surface chemistry analysis measured an increase in oxygenated functional groups and cationic minerals on the biochar surface, which likely enhanced retention through cationic bridging or the development of an organomineral layer on the biochar surface. Results indicated biochar amendment to agricultural treatment systems receiving $\mathrm{N}$ runoff may reduce the risk of $\mathrm{N}$ leaching.
\end{abstract}

Keywords: biochar; agriculture runoff; nitrate leaching

\section{Introduction}

Biochar is a carbon (C)-rich byproduct of pyrolysis, in which biomass is heated in the absence of oxygen. Biochar generally has a large surface area, alkaline $\mathrm{pH}$, high water holding capacity, and a high cation exchange capacity [1,2], but properties can vary greatly depending on pyrolysis conditions. Biochar has typically been used as a soil amendment to improve soil nutrient availability, water holding capacity, enhance plant-microbe interactions, reduce nutrient leaching, and sequester carbon [3].

Multiple studies have shown that biochar amendment to agricultural soils can reduce nitrogen (N) leaching [4-12] and gaseous emissions [13,14]. Laboratory column studies have found biochar can reduce nitrate $\left(\mathrm{NO}_{3}{ }^{-}\right)$and ammonium $\left(\mathrm{NH}_{4}{ }^{+}\right)$subsurface leaching following synthetic $\mathrm{N}$ fertilizer application from $5 \%$ to $37 \%$ and $15 \%$ to $35 \%$, respectively [4-10]. Additionally, biochar amended soils receiving manure applications in column studies have reported reductions in total $\mathrm{N}$ (TN) ranging from $11 \%$ to $59 \%$ [11,12]. Similar results have been reported in field studies [8,15-21], highlighting the potential use of biochar to better manage $\mathrm{N}$ leaching in agricultural soil systems.

The mechanisms for the reduction in soil $\mathrm{N}$ leaching following biochar amendment is not well established. Studies have suggested that biochar amendment may reduce mineralization of ORG-N [22], 
possibly through ORG-N binding [23], preventing conversion to mobile inorganic $\mathrm{N}$ species, which are prone to leaching. However, others have suggested the additional $\mathrm{C}$ from biochar can enhance mineralization rates, with increases ranging from $40 \%$ to $220 \%[9,24]$. Following mineralization, $\mathrm{N}$ leaching may be reduced through $\mathrm{NH}_{4}{ }^{+}$binding to biochar as a result of the sorption $[10,25,26]$. Biochar's ability to bind and immobilize $\mathrm{NH}_{4}{ }^{+}$may also prevent nitrification, thereby reducing $\mathrm{NO}_{3}{ }^{-}$concentrations and leaching [27]. However, some incubation studies have found biochar may increase nitrification rates $[24,28]$ potentially due to the increase in soil $\mathrm{pH}$. Additionally, multiple field studies have contradicted $\mathrm{NH}_{4}{ }^{+}$binding as the primary mechanism for reduction in $\mathrm{N}$ leaching, as soil extractions have identified $\mathrm{NO}_{3}{ }^{-}$to be the primary inorganic $\mathrm{N}$ species in biochar-amended soils $[16,18-20,29,30]$. Laboratory studies have found low $\mathrm{NO}_{3}{ }^{-}$sorption capacities for unprocessed biochar [31-34]. Thus, $\mathrm{NO}_{3}{ }^{-}$bound to biochar amended soil suggests that biochar properties are altered following soil amendment. Proposed mechanisms for this phenomenon include abiotic and biotic oxidation altering surface functional groups, development of complex organomineral layers, or unconventional hydrogen bonding $[29,35,36]$. Additionally, biochar has been shown to impact gaseous emissions of nitrous oxide $\left(\mathrm{N}_{2} \mathrm{O}\right)$, which may be related to $\mathrm{NO}_{3}{ }^{-}$binding in the soil, or an increase in soil $\mathrm{pH}$ due to biochar buffering capacity $[13,14,16,37,38]$.

While most studies focus efforts on examining impacts of biochar amendment to agricultural cropping systems, there is potential to integrate biochar into agricultural treatment systems. Farmstead runoff from silage bunker pads or feedlots have high $\mathrm{N}$ concentrations [39-41] posing risks to water quality. Producers often use treatment systems to reduce $\mathrm{N}$ losses to surface water, such as vegetative treatment areas, which promote infiltration [42]. However, there is growing evidence that many agricultural treatment systems aimed at reducing runoff losses may not adequately address issues related to groundwater contamination, particularly from $\mathrm{NO}_{3}{ }^{-}$leaching $[19,43-45]$. Biochar may be a suitable amendment to reduce $\mathrm{NO}_{3}{ }^{-}$leaching through these vegetative treatment areas to reduce groundwater impacts. However, more information on the impact of $\mathrm{N}$ leaching when biochar is integrated in soil based treatment systems is needed to improve integration strategies.

\section{Materials and Methods}

The objectives of this study are to assess the impact of repeated $\mathrm{N}$ applications on $\mathrm{N}$ soil retention, leaching and gaseous emissions from biochar amended soil columns. To better understand these impacts, different $\mathrm{N}$ forms were applied to soil columns at varying rates. The $\mathrm{N}$ retained in biochar-amended soils, $\mathrm{N}$ leached through the columns, and the $\mathrm{N}_{2} \mathrm{O}$ and ammonia $\left(\mathrm{NH}_{3}\right)$ emissions were quantified over ten weeks.

\subsection{Soil Charracteristics}

An engineered soil was obtained from a local landscaping company in Madison, WI, USA. The soil was a sandy loam with $68 \%$ sand, $21 \%$ silt, and $11 \%$ clay [46]. The soil had a pH of 6.3 and a N, phosphorus $(\mathrm{P})$, and potassium $(\mathrm{K})$ content of $0.66,0.20$, and $0.33 \mathrm{~g} \mathrm{~kg}^{-1}$, respectively.

\subsection{Biochar Production and Properites}

Corncob biochar was produced by Biochar Options, LLC at a production temperature of $400{ }^{\circ} \mathrm{C}$ $\left(\mathrm{BC}_{1}\right)$ and $700{ }^{\circ} \mathrm{C}\left(\mathrm{BC}_{2}\right)$ for a holding time of one hour under oxygen limiting conditions. Following production, biochar was crushed and sieved through a number ten mesh sieve (pore size $2 \mathrm{~mm}$ ). Following production, a portion of the $700{ }^{\circ} \mathrm{C}$ biochar was then oxidized $\left(\mathrm{BC}_{3}\right)$, as oxidized biochar has shown enhanced $\mathrm{NO}_{3}{ }^{-}$sorption. Biochar was oxidized by suspending a $2.5 \%$ biochar to a liquid solution of $6 \mathrm{mmol} \mathrm{g}^{-1}$ sodium bromide $(\mathrm{NaBr})$ and $50 \mathrm{mmol} \mathrm{g}^{-1}$ sodium hypochlorite $(\mathrm{NaClO})$. The $\mathrm{pH}$ was adjusted to 11 using hydrochloric acid $(\mathrm{HCl})$ and agitated for six hours at room temperature [36]. The solution was then filtered, and biochar was washed five times by submerging in deionized water (DI) for $10 \mathrm{~min}$ followed by vacuum filtration. $\mathrm{BC}_{3}$ was then sieved through a number ten mesh sieve (pore size $2 \mathrm{~mm}$ ). 
Biochar was characterized for elemental content and $\mathrm{pH}$ (Table S1). Carbon, hydrogen $(\mathrm{H})$, and N was determined following ASTM D5373 using a PerkinElmer Elemental Analyzer (PerkinElmer, Waltham, MA). Oxygen content was determined by subtracting C, H, N, ash (via ASTM D1102), and moisture (via ASTM E871). The $\mathrm{pH}$ was measured using a 1:20 ratio of biochar to DI suspension and measuring $\mathrm{pH}$ with a HACH HQ440d Benchtop Multi Meter.

\subsection{Experimental Design}

Columns were constructed out of $3.8 \mathrm{~cm}$ diameter PVC pipe with a height of $36 \mathrm{~cm}$. A fiberglass screen filter was attached to the bottom of the column. On top of the screen, $100 \mathrm{~g}$ of acid washed pea gravel (2-4 mm) was added. Columns were then packed with $300 \mathrm{~g}$ of soil, or for those columns containing biochar treatments, a $5 \%(w t / w t)$ biochar to soil mixture, which was incorporated into the entire depth of the soil column. Biochar and soil was mixed in $50 \mathrm{~g}$ increments by adding soil and biochar to plastic bottle and inverting several times. Columns were filled by adding $50 \mathrm{~g}$ of soil and then compacting with a $125 \mathrm{~g}$ weight dropped from a height of $15 \mathrm{~cm}$ two times and repeated until $300 \mathrm{~g}$ of soil mixture was added. Four column treatments included the control (sandy loam soil), $5 \% \mathrm{BC}_{1}$ amended, $5 \% \mathrm{BC}_{2}$ amended, and $5 \% \mathrm{BC}_{3}$ amended (Table 1). Columns were placed in a climate-controlled room at a temperature of $20{ }^{\circ} \mathrm{C}$ and relative humidity of $50 \%$.

Table 1. Study experimental design setup, weekly application concentrations, weekly application rates, total mass loading, and average column soil bulk density.

\begin{tabular}{|c|c|c|c|c|c|c|}
\hline $\begin{array}{l}\text { Treatment } \\
\text { Group }\end{array}$ & N Applied & $\begin{array}{l}\text { Concentration } \\
\left(m g \mathrm{~N} \mathrm{~L}^{-1}\right)\end{array}$ & $\begin{array}{c}\text { Rate } \\
(k g \text { N ha } \\
(1)\end{array}$ & $\begin{array}{c}\text { Total } \\
\text { Mass Loading } \\
(\mathrm{mg} \mathrm{N})\end{array}$ & Treatment & $\begin{array}{c}\text { Bulk } \\
\text { Density } \\
\left(\mathrm{g} \mathrm{cm}^{-3}\right)\end{array}$ \\
\hline 1 & $\begin{array}{l}\text { ORG-N } \\
\text { Low }\end{array}$ & 150 & 198 & 225 & $\begin{array}{c}\text { Control } \\
2.5 \% \mathrm{BC}_{1}\end{array}$ & $\begin{array}{l}1.70 \pm 0.01 \\
1.39 \pm 0.04 \\
\end{array}$ \\
\hline 2 & $\begin{array}{l}\text { ORG-N } \\
\text { High }\end{array}$ & 2500 & 3306 & 3750 & $\begin{array}{c}\text { Control } \\
2.5 \% \mathrm{BC}_{1}\end{array}$ & $\begin{array}{l}1.71 \pm 0.03 \\
1.39 \pm 0.03 \\
\end{array}$ \\
\hline 3 & $\begin{array}{c}\mathrm{NH}_{4}^{+} \\
\text {Low }\end{array}$ & 50 & 66 & 75 & $\begin{array}{c}\text { Control } \\
2.5 \% \mathrm{BC}_{1}\end{array}$ & $\begin{array}{l}1.64 \pm 0.08 \\
1.42 \pm 0.02 \\
\end{array}$ \\
\hline 4 & $\begin{array}{l}\mathrm{NH}_{4}^{+} \\
\mathrm{High}\end{array}$ & 1250 & 1653 & 1875 & $\begin{array}{c}\text { Control } \\
2.5 \% \mathrm{BC}_{1}\end{array}$ & $\begin{array}{l}1.72 \pm 0.05 \\
1.41 \pm 0.01\end{array}$ \\
\hline 5 & $\mathrm{NO}_{3}{ }^{-}$ & 20 & 26 & 30 & $\begin{array}{c}\text { Control } \\
2.5 \% \mathrm{BC}_{1} \\
2.5 \% \mathrm{BC}_{2} \\
2.5 \% \mathrm{BC}_{3}\end{array}$ & $\begin{array}{l}1.69 \pm 0.03 \\
1.38 \pm 0.01 \\
1.39 \pm 0.01 \\
1.53 \pm 0.11\end{array}$ \\
\hline
\end{tabular}

Soil columns were grouped into five trials where each group received different $\mathrm{N}$ applications (Table 1). Treatment group one consisted of a control and $5 \% \mathrm{BC}_{1}$ receiving repeated applications of low ORG-N blend (150 mg ORG-N L ${ }^{-1}$ ), similar to concentrations in silage bunker runoff [41]. Treatment group two consisted of control and $5 \% \mathrm{BC}_{1}$ receiving repeated high ORG-N applications $(2500 \mathrm{mg}$ ORG-N L ${ }^{-1}$ ), similar to concentrations in manure [11]. The ORG-N solution in treatment groups one and two were made up of 50\% arginine, $40 \%$ glycine, and $10 \%$ alanine, which are abundant ORG-N forms in manure [47]. Group three consisted of a control and $5 \% \mathrm{BC}_{1}$ receiving repeated low $\mathrm{NH}_{4}{ }^{+}-\mathrm{N}$ applications (50 $\mathrm{mg} \mathrm{NH}_{4}{ }^{+}-\mathrm{N} \mathrm{L}^{-1}$ ), similar to concentrations in silage bunker runoff [41]. Treatment group four consisted of a control and $5 \% \mathrm{BC}_{1}$ receiving repeated high $\mathrm{NH}_{4}{ }^{+}-\mathrm{N}$ applications $(1,250 \mathrm{mg}$ $\mathrm{NH}_{4}{ }^{+}-\mathrm{N} \mathrm{L}^{-1}$ ), similar to concentrations in manure [11]. Group five consisted of control, $5 \% \mathrm{BC}_{1}, 5 \%$ $\mathrm{BC}_{2}$, and $5 \% \mathrm{BC}_{3}$ treatments receiving repeated $\mathrm{NO}_{3}{ }^{-}-\mathrm{N}$ applications $\left(20 \mathrm{mg} \mathrm{NO}_{3}{ }^{-}-\mathrm{N} \mathrm{L}^{-1}\right)$, similar to tile drainage effluent [48]. More treatments were present in group five to identify if production temperature or oxidation impacted $\mathrm{NO}_{3}{ }^{-}$leaching. The $\mathrm{NH}_{4}{ }^{+}-\mathrm{N}$ and $\mathrm{NO}_{3}{ }^{-}-\mathrm{N}$ solutions were prepared using ammonium chloride $\left(\mathrm{NH}_{4} \mathrm{Cl}\right)$ and sodium nitrate $\left(\mathrm{NaNO}_{3}\right)$, respectively. Solutions ionic strength was adjusted to be representative of manure, silage bunker runoff, or tile drainage effluent by adding monopotassium phosphate $\left(\mathrm{KH}_{2} \mathrm{PO}_{4}\right)$. Target ionic strengths were estimated by using electrical 
conductivity values reported for manure $\left(17.00 \mathrm{~ms} \mathrm{~cm}^{-1}\right)$ [11], silage bunker runoff $\left(1.24 \mathrm{~ms} \mathrm{~cm}^{-1}\right)$ [41], and tile drainage effluent $\left(0.38 \mathrm{~ms} \mathrm{~cm}^{-1}\right)$ [48] and applying the Snoeyink and Jenkins [49] relationship to determine ionic strength. The amount of $\mathrm{KH}_{2} \mathrm{PO}_{4}$ added to the solution was then determined using Equation (1):

$$
I=\frac{1}{2} \sum C_{i} Z_{i}^{2}
$$

where $I$ is the ionic strength, $C_{i}$ is the molar concentration $(\mathrm{M})$ of an ion, and $Z_{i}$ is the charge number.

Solutions were applied at a volume of $150 \mathrm{~mL}$ or $13.2 \mathrm{~cm}$, which corresponds to a $\mathrm{N}$ application rate for groups one, two, three, four, and five of 198, 3306, 66, 1653, and $26 \mathrm{~kg} \mathrm{~N} \mathrm{ha}^{-1}$, respectively (Table 1). Applications occurred once a week (seven days between applications) for ten weeks. During application, columns were allowed to drain completely which typically took between one to two hours. Following EPA guidelines, samples were immediately analyzed for $\mathrm{pH}$ and preserved and stored at $4{ }^{\circ} \mathrm{C}$ (no longer than 28 days). Samples were analyzed for total phosphorus (TP), total Kjeldahl nitrogen (TKN), ammoniacal nitrogen (TAN), nitrates $\left(\mathrm{NO}_{3}{ }^{-}+\mathrm{NO}_{2}{ }^{-}-\mathrm{N}\right)$, and nitrite $\left(\mathrm{NO}_{2}{ }^{-} \mathrm{N}\right)$ following USEPA approved methodology (Table S2).

A dynamic flow through chamber was used to measure $\mathrm{NH}_{3}$ emissions from the soil. The column walls served as the chamber anchor and a PVC cap with inlet and outlet ports served as the lid. The lid was sealed to the column using rubber stripping and hose clamps. A SKC PCXR4 Universal Sample Pump (SKC, Eighty Four, PA) pumped ambient air into the chamber at a flow rate of $250 \mathrm{~mL}$ $\mathrm{min}^{-1}$. Emissions were then recorded every $15 \mathrm{~s}$ for 5 min using a MAS $5 \mathrm{X}$ gas monitor (Mine Safety Appliances, Cranberry Township, PA). All connection tubing was Teflon to minimize chemical reactions. Measurements were taken 1, 6, 24, and $72 \mathrm{~h}$ after weekly applications. Flux of $\mathrm{NH}_{3}$ [50] was determined following Equation (2):

$$
J=\frac{Q\left(C_{e q}-C_{i}\right)}{A}
$$

where $J$ is the $\mathrm{NH}_{3}$ flux $\left(\mathrm{mg} \mathrm{NH} \mathrm{NH} \mathrm{m}_{3}-\mathrm{N} \mathrm{s}^{-1}\right), Q$ is the dynamic chamber flow rate $\left(\mathrm{m}^{3} \mathrm{~s}^{-1}\right), C_{e q}$ is the equilibrium concentration $\left(\mathrm{mg} \mathrm{NH}_{3} \mathrm{~m}^{-3}\right), \mathrm{C}_{i}$ is the initial $\mathrm{NH}_{3}$ concentration $\left(\mathrm{mg} \mathrm{NH}_{3} \mathrm{~m}^{-3}\right)$, and $A$ is the soil surface area $\left(\mathrm{m}^{2}\right)$. Total loss gas (loss due to chamber or sample lines) was determined to be negligible. Cumulative emissions were determined using fluxes and multiplying by the time between sampling points.

A static chamber was used for $\mathrm{N}_{2} \mathrm{O}$ emissions following GRACEnet protocol [51]. The column walls served as the anchor and the lid was a PVC cap with a septum installed. The PVC lid was sealed using the same method as the dynamic chamber. Sample collection took place once a week $24 \mathrm{~h}$ after nutrient application. Gas was measured by sampling headspace gas at 12-min intervals for $36 \mathrm{~min}$. Glass $5.9 \mathrm{~mL}$ Exetainer vials (Labco Limited, Buckinghamshire, UK) were overcharged with $10 \mathrm{~mL}$ gas samples. Gas concentrations were measured by gas chromatography with a $15 \mathrm{mCi} 63 \mathrm{Ni}$ electron capture detector for $\mathrm{N}_{2} \mathrm{O}$ (Agilent 7890A GC system). Flux of $\mathrm{N}_{2} \mathrm{O}$ was determined following Equation (3) [51]:

$$
F=\frac{\left(S-V_{c}\right)}{A}
$$

where $F$ is the $\mathrm{N}_{2} \mathrm{O}$ flux $\left(\mathrm{mg} \mathrm{N}_{2} \mathrm{O}-\mathrm{N} \mathrm{m}^{-2} \mathrm{~h}^{-1}\right), V_{c}$ is the chamber volume $\left(\mathrm{m}^{3}\right), A$ is the soil surface area $\left(\mathrm{m}^{2}\right)$, and $S$ is the slope of change in concentration over time $\left(\mathrm{mg} \mathrm{N}_{2} \mathrm{O} \mathrm{m}^{-2} \mathrm{~h}^{-1}\right)$, which was calculated based on the concentration linear regression. Cumulative emissions were determined using fluxes and multiplying them by the time between sampling points. Using a mass balance approach, any unaccounted influent $\mathrm{N}$ (i.e., influent $\mathrm{N}$ subtracted by effluent $\mathrm{N}$, retained $\mathrm{N}, \mathrm{N}_{2} \mathrm{O}$, and $\mathrm{NH}_{3}$ ) was assumed to be lost as $\mathrm{N}_{2}$ through denitrification. 


\subsection{Soil and Biochar Analysis}

Following ten weeks of nutrient applications, soil was removed from each column. Soil was dried at $50{ }^{\circ} \mathrm{C}$ for $48 \mathrm{~h}$ [52], ground to pass through a $2 \mathrm{~mm}$ sieve, and stored at $4{ }^{\circ} \mathrm{C}$ until analysis. Soil $\mathrm{pH}$ was determined with a HACH HQ440d Benchtop Multi Meter $\mathrm{pH}$ probe after diluting soil 1:2.5 by mass with DI [53]. Extractable $\mathrm{NO}_{3}{ }^{-}-\mathrm{N}$ and $\mathrm{NH}_{4}{ }^{+}-\mathrm{N}$ were determined using a modified $\mathrm{KCl}$ extraction method, as past studies have reported standard $\mathrm{KCl}$ soil extractions underestimate biochar $\mathrm{NO}_{3}{ }^{-}-\mathrm{N}$ content $[30,35,54]$. It has been suggested that $\mathrm{KCl}$ extractions for biochar amended soils be conducted at higher temperatures $\left(>50^{\circ} \mathrm{C}\right)$ for a long duration to ensure extraction efficiency [35]. Methods outlined in Walsh et al. [55] were followed for inorganic N extractions. Soil samples were suspended with $2 \mathrm{M} \mathrm{KCl}$ at a ratio of 1:10 (wt/vol) and placed on a temperature-controlled shaker at $50^{\circ} \mathrm{C}$ and $100 \mathrm{rpm}$ for $24 \mathrm{~h}$. Suspensions were then vacuum filtered through $1.5 \mu \mathrm{m}$ filter paper and collected. The soil was rinsed twice by pouring $25 \mathrm{~mL}$ of DI over the biochar and vacuum filtering. Filtrate was preserved and stored at $4{ }^{\circ} \mathrm{C}$ (no longer than 28 days) until analyzed for $\mathrm{NO}_{3}+\mathrm{NO}_{2}-\mathrm{N}_{\text {and }}$ TAN following EPA approved methods (Table S2). Additionally, soil samples were analyzed for TKN using a copper catalyst digestion method [56].

A portion of biochar was removed from the soil and analyzed for changes in surface functional groups. Fourier-transform infrared spectroscopy (FTIR) spectra were analyzed with a PerkinElmer Spectrum 100 FT-IR Spectrometer (PerkinElmer, Waltham, MA) using potassium bromide (KBr) pellets containing $0.3 \%$ of finely ground biochar [57]. Spectra were obtained from 550 to $4000 \mathrm{~cm}^{-1}$ over 100 scans with a resolution of $4 \mathrm{~cm}^{-1}$. To illicit potential nitrogen binding mechanisms X-ray photo-electron spectroscopy (XPS) analyses using a Thermo K-Alpha X-ray Photoelectron Spectrometer (Thermo Scientific, Waltham, MA) was used. Survey spectra were scanned from 1350 to $0 \mathrm{eV}$ binding energy range and recorded with a pass energy of $50 \mathrm{eV}$ over 20 scans. Thermo Avantage version 5.9 was used for peak identification and fitting.

\subsection{Data Analysis}

Analysis was performed in SAS [58]. Repeated measures (Proc Mixed) using first-order auto-regressive variance-covariance structure was used to determine statistical differences of cumulative effluent nutrient content between treatments. One-way analysis of variance (ANOVA) with Fisher's least significant difference test (LSD) was conducted to compare influent and effluent nutrient concentrations for each event for water quality parameters and soil $\mathrm{N}$ content following applications.

\section{Results}

\subsection{Organic Nitrogen Application (Treatment Groups 1 and 2)}

For weekly applications of ORG-N low (treatment group 1), the biochar amended columns significantly reduced cumulative TN leaching by $15.8 \%$ and $\mathrm{NO}_{3}{ }^{-}-\mathrm{N}$ leaching by $16.5 \%$ compared to the control (Figure 1A and Figure S1A). Most of the leachate was in the form of $\mathrm{NO}_{3}{ }^{-} \mathrm{N}$. The reduced leaching was because the biochar amendment significantly increased the TN retained in the soil (Figure 2A) where most of the $\mathrm{N}$ retained was ORG-N. The $\mathrm{NO}_{3}{ }^{-}-\mathrm{N}$ bound in the soil/biochar matrix was more than double the control, but was only a small fraction of the overall TN retained (Table 2). Gaseous emission losses of $\mathrm{NH}_{3}$ was negligible, and $\mathrm{N}_{2} \mathrm{O}$ accounted for $2.3 \%$ and $1.2 \%$ of the influent TN applied for control and biochar columns (Figure 2A), respectively, and were not statistically different. For the control and biochar-amended columns $36.2 \%$ and $24.5 \%$ of the total $\mathrm{N}$ applied was calculated to be lost as $\mathrm{N}$ emissions other than $\mathrm{NH}_{3}$ or $\mathrm{N}_{2} \mathrm{O}$ (Figure $2 \mathrm{~A}$ ). 


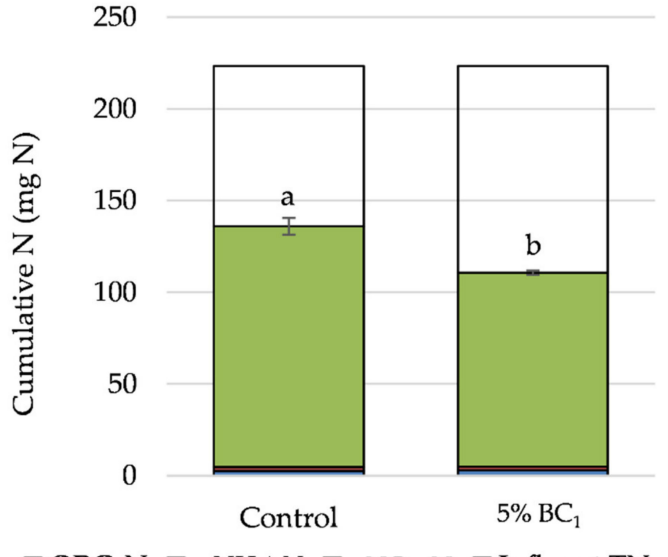

$\square$ ORG-N $\square \quad \mathrm{NH}_{4}{ }^{+}-\mathrm{N} \quad \square \quad \mathrm{NO}_{3}{ }^{-}-\mathrm{N} \quad \square$ Influent $\mathrm{TN}$

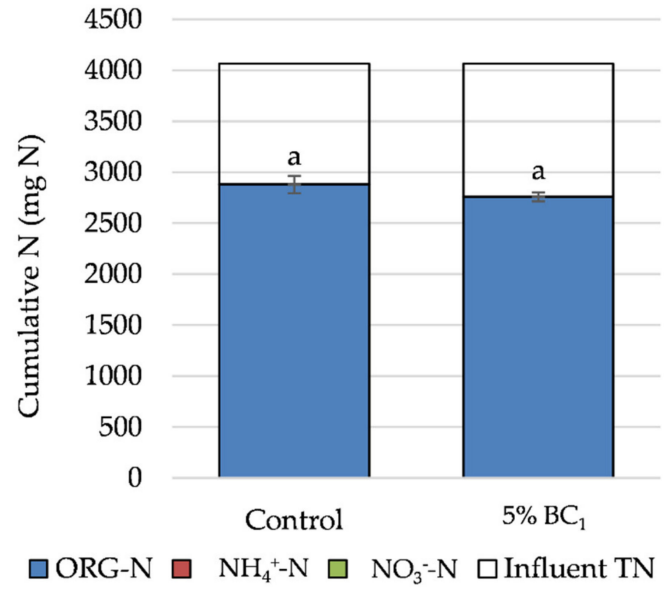

(B)

(A)

Figure 1. Cumulative mass of influent and effluent nitrogen $(\mathrm{N})(\mathrm{mg} \mathrm{N})$ for control and biochar columns receiving (A) organic nitrogen (ORG-N) low (treatment group 1) and (B) ORG-N high (treatment group 2) application rates. Entire bar (with no fill) represents influent total nitrogen (TN), where entire solid bar represents effluent TN. Individual N species in the effluent are denoted based on color (blue, red, or green). Error bars represent standard deviation of effluent TN between triplicate columns for treatment. Letters signify statistically significant difference between treatments.

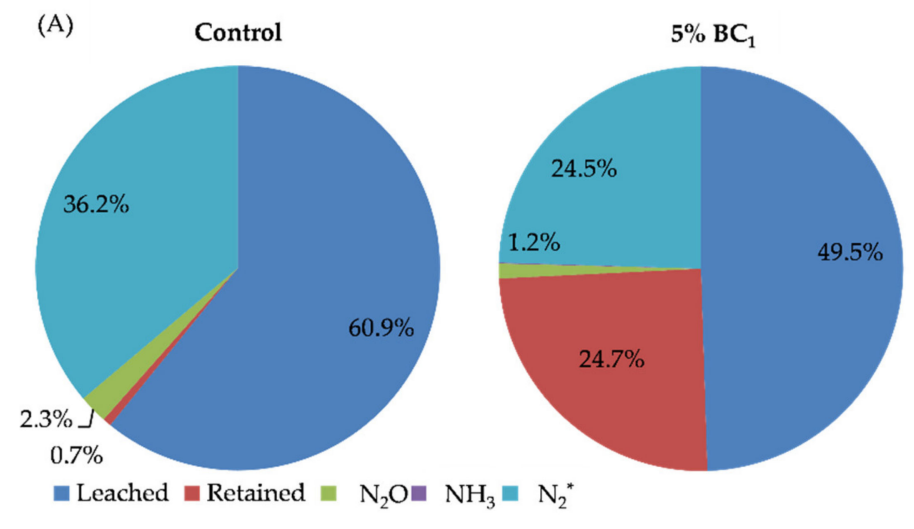

(B)

Control $5 \% \mathrm{BC}_{1}$

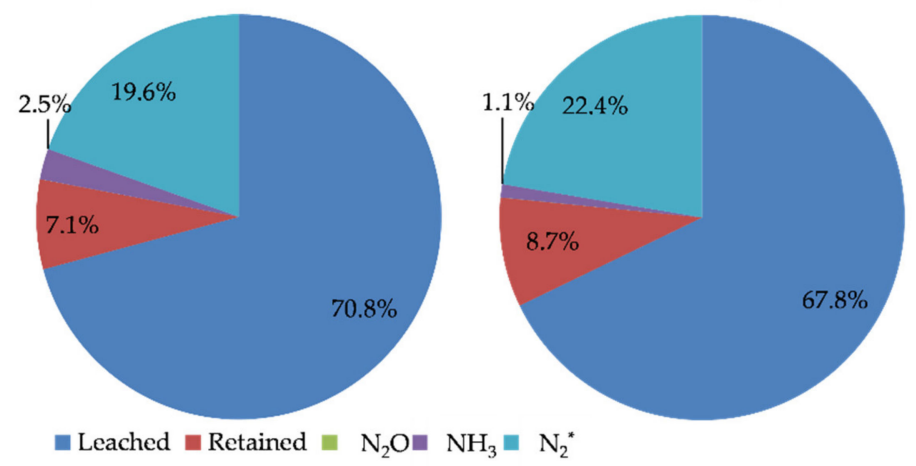

Figure 2. Nitrogen mass balance for influent TN for columns receiving (A) ORG-N low (treatment group (1) and (B) ORG-N high (treatment group (2) application rates. *Assumed that influent TN unaccounted for in effluent $\mathrm{N}$, retained $\mathrm{N}, \mathrm{N}_{2} \mathrm{O}$, or $\mathrm{NH}_{3}$ was assumed to be lost as $\mathrm{N}_{2}$. 
Table 2. Change ${ }^{\dagger}$ in soil $\mathrm{N}$ for ORG-N low (treatment group 1), ORG-N high (treatment group 2), $\mathrm{NH}_{4}{ }^{+}-\mathrm{N}$ low (treatment group 3), $\mathrm{NH}_{4}{ }^{+}-\mathrm{N}$ high (treatment group 4) and $\mathrm{NO}_{3}{ }^{-}-\mathrm{N}$ (treatment group 5) after 10 weeks of nutrient application. Values are means (standard deviation) of triplicates. Different letters represent significant difference $(p=0.05)$ between soil $\mathrm{N}$ within application group.

\begin{tabular}{ccccccc}
\hline Application + & Treatment & $\begin{array}{c}\mathbf{N H}_{4}{ }^{+}-\mathbf{N} \\
(\mathbf{m g ~ N})\end{array}$ & $\begin{array}{c}\mathbf{N O}_{3}-\mathbf{N} \\
(\mathbf{m g ~ N})\end{array}$ & $\begin{array}{c}\text { TKN } \\
(\mathbf{m g ~ N})\end{array}$ & $\begin{array}{c}\text { ORG-N } \neq \\
(\mathbf{m g ~ N})\end{array}$ & $\begin{array}{c}\text { TN } \\
(\mathbf{m g ~ N})\end{array}$ \\
\hline \multirow{2}{*}{ ORG-N Low } & Control & $10.52(1.28)^{\mathrm{a}}$ & $0.91(1.10)^{\mathrm{a}}$ & $0.60(8.41)^{\mathrm{a}}$ & $-9.91(7.75)^{\mathrm{a}}$ & $1.51(9.50)^{\mathrm{a}}$ \\
& $\mathrm{BC}_{1}$ & $10.52(2.19)^{\mathrm{a}}$ & $6.76(1.00)^{\mathrm{b}}$ & $63.64(27.00)^{\mathrm{b}}$ & $53.13(26.24)^{\mathrm{b}}$ & $55.21(26.39)^{\mathrm{b}}$ \\
\hline \multirow{2}{*}{ ORG-N High } & Control & $180.61(9.60)^{\mathrm{a}}$ & $-3.65(0.07)^{\mathrm{a}}$ & $294.32(3.59)^{\mathrm{a}}$ & $113.70(6.20)^{\mathrm{a}}$ & $290.66(3.54)^{\mathrm{a}}$ \\
& $\mathrm{BC}_{1}$ & $217.15(17.68)^{\mathrm{a}}$ & $-4.17(1.04)^{\mathrm{a}}$ & $360.04(46.66)^{\mathrm{a}}$ & $142.89(60.80)^{\mathrm{a}}$ & $326.47(16.26)^{\mathrm{a}}$ \\
\hline \multirow{2}{*}{$\mathrm{NH}_{4}{ }^{+}-\mathrm{N}$ Low } & Control & $2.42(1.51)^{\mathrm{a}}$ & $-0.40(0.71)^{\mathrm{a}}$ & $0.50(0.83)^{\mathrm{a}}$ & $-2.89(3.09)^{\mathrm{a}}$ & $0.10(0.26)^{\mathrm{a}}$ \\
& $\mathrm{BC}_{1}$ & $8.92(3.22)^{\mathrm{a}}$ & $3.58(0.27)^{\mathrm{b}}$ & $8.52(2.21)^{\mathrm{b}}$ & $-0.41(1.08)^{\mathrm{a}}$ & $12.09(2.44)^{\mathrm{b}}$ \\
\hline \multirow{2}{*}{$\mathrm{NH}_{4}{ }^{+}-\mathrm{N}$ High } & Control & $150.76(13.98)^{\mathrm{a}}$ & $17.54(5.89)^{\mathrm{a}}$ & $107.40(3.09)^{\mathrm{a}}$ & $-43.36(11.40)^{\mathrm{a}}$ & $124.94(7.95)^{\mathrm{a}}$ \\
& $\mathrm{BC}_{1}$ & $132.51(6.69)^{\mathrm{a}}$ & $91.85(8.47)^{\mathrm{b}}$ & $116.82(8.98)^{\mathrm{a}}$ & $-15.69(11.70)^{\mathrm{b}}$ & $208.68(17.36)^{\mathrm{b}}$ \\
\hline \multirow{2}{*}{$\mathrm{NO}_{3}{ }^{-}-\mathrm{N}$} & $\mathrm{Control}$ & $1.98(0.72)^{\mathrm{a}}$ & $-2.25(0.12)^{\mathrm{a}}$ & $-6.99(4.24)^{\mathrm{ab}}$ & $-8.96(3.56)^{\mathrm{b}}$ & $-9.24(4.13)^{\mathrm{a}}$ \\
& $\mathrm{BC}_{1}$ & $9.98(3.99)^{\mathrm{b}}$ & $-2.79(0.08)^{\mathrm{a}}$ & $-4.73(3.79)^{\mathrm{a}}$ & $-14.71(5.07)^{\mathrm{bc}}$ & $-7.52(3.76)^{\mathrm{a}}$ \\
& $\mathrm{BC}_{2}$ & $5.56(1.45)^{\mathrm{ab}}$ & $6.73(0.94)^{\mathrm{c}}$ & $2.61(1.55)^{\mathrm{c}}$ & $-2.95(3.00)^{\mathrm{a}}$ & $9.34(2.04)^{\mathrm{b}}$ \\
& $\mathrm{BC}_{3}$ & $7.62(0.74)^{\mathrm{b}}$ & $0.26(0.76)^{\mathrm{b}}$ & $-11.74(2.12)^{\mathrm{b}}$ & $-19.35(2.69)^{\mathrm{c}}$ & $-11.48(1.79)^{\mathrm{a}}$ \\
\hline
\end{tabular}

Different letters signify significant difference $(p<0.05)$ between control and biochar treatments for a specific parameter within a treatment group. + Data presented in tables is the change in soil $\mathrm{N}$ content or the final soil $\mathrm{N}$ content subtracted by the initial soil $\mathrm{N}$ content. Negative values indicate that species of $\mathrm{N}$ in the soil was converted or lost over the study period. $\ddagger$ Calculated from ORG-N $=\mathrm{TKN}-\mathrm{NH}_{4}{ }^{+}-\mathrm{N}$.

For ORG-N high applications (treatment group 2), that were designed to be similar to manure concentrations, there was no significant difference between the two treatments for cumulative TN leaching (Figure 1B). The soil TN increased for both treatments, primarily in the form of $\mathrm{NH}_{4}{ }^{+}-\mathrm{N}$ and ORG-N, but treatments were not significantly different (Table 2). Emissions of $\mathrm{N}_{2} \mathrm{O}$ were negligible; however cumulative $\mathrm{NH}_{3}$ emissions accounted for $2.5 \%$ and $1.1 \%$ of the influent $\mathrm{TN}$ for the control and biochar columns, respectively (Figure 2B). Total influent $\mathrm{N}$ lost as emissions other than $\mathrm{N}_{2} \mathrm{O}$ or $\mathrm{NH}_{3}$ for control and biochar columns was $19.6 \%$ and $22.4 \%$, respectively (Figure 2B).

\subsection{Ammonium Applications (Treatment Groups 3 and 4)}

Following weekly applications of $\mathrm{NH}_{4}{ }^{+}-\mathrm{N}$ low application (treatment group 3), that were designed to be similar to silage bunker runoff $\mathrm{N}$ concentrations, cumulative $\mathrm{TN}$ in leachate was significantly lower for the biochar amended columns (Figure 3A). Most of the leachate was in the form of $\mathrm{NO}_{3}{ }^{-}-\mathrm{N}$. Biochar amendment significantly reduced $\mathrm{NO}_{3}{ }^{-}-\mathrm{N}$ leaching by $14.6 \%$ compared to the control (Figure S1B). Biochar amendment resulted in a significant increase in soil TN retention (Figure $4 \mathrm{~A}$ ). BC $\mathrm{BC}_{1}$ amended soils had significantly greater $\mathrm{NO}_{3}{ }^{-}-\mathrm{N}$ retention than the control soil (Table 2). Emissions as $\mathrm{N}_{2} \mathrm{O}$ accounted for $1.7 \%$ and $2.0 \%$ of the losses of the influent TN applied for control and biochar columns (Figure 4A). Nitrogen calculated to be lost as emissions other than $\mathrm{N}_{2} \mathrm{O}$ or $\mathrm{NH}_{3}$ for control and biochar columns was $11.9 \%$ and $10.4 \%$, respectively.

Following $\mathrm{NH}_{4}{ }^{+}-\mathrm{N}$ high application (treatment group 4), designed to be similar to manure land applications, biochar columns significantly decreased TN leaching compared to the control (Figure 3B). There was not a significant difference between TAN in leachate between treatments. Biochar columns reduced $\mathrm{NO}_{3}{ }^{-}-\mathrm{N}$ leaching significantly by $25 \%$ (Figure S1C). Biochar amendment significantly increased the TN retained in the soil compared to the control (Figure 4B). There was not a significant difference in soil $\mathrm{NH}_{4}{ }^{+}-\mathrm{N}$ retention between treatments, but biochar amended soils significantly increased the retention of $\mathrm{NO}_{3}{ }^{-}-\mathrm{N}$ and reduced the loss of the ORG-N originally contained within the soil (Table 2). Emissions from the columns as $\mathrm{NH}_{3}$ were negligible. $\mathrm{N}_{2} \mathrm{O}$ emissions accounted for $0.7 \%$ and $0.4 \%$ of the cumulative influent $\mathrm{N}$ for control and biochar columns, respectively. Based on the TN applied to the columns over the study, $\mathrm{N}$ lost as emissions other than $\mathrm{N}_{2} \mathrm{O}$ and $\mathrm{NH}_{3}$ was calculated to be $6.8 \%$ and $9.4 \%$ for control and biochar columns, respectively. 


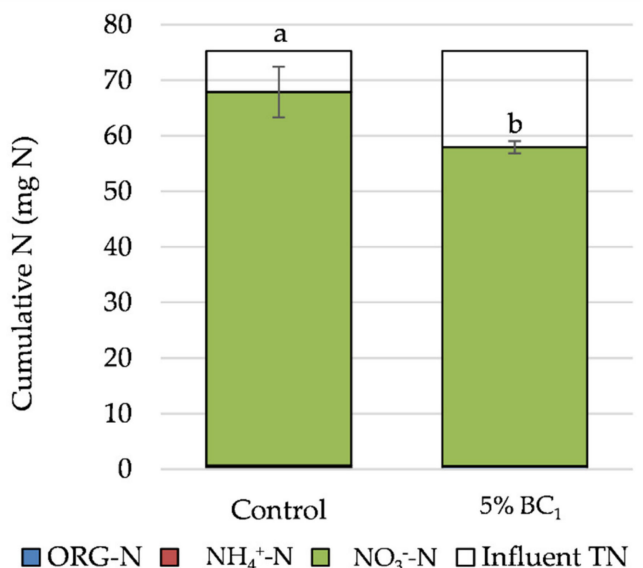

(A)

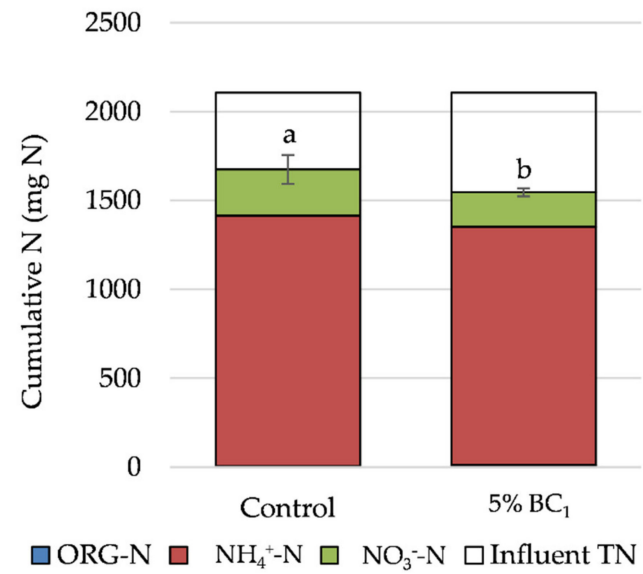

(B)

Figure 3. Cumulative mass of influent and effluent $\mathrm{N}(\mathrm{mg} \mathrm{N})$ for control and biochar columns receiving (A) $\mathrm{NH}_{4}{ }^{+}-\mathrm{N}$ low (treatment group 3), and (B) $\mathrm{NH}_{4}{ }^{+}-\mathrm{N}$ high (treatment group 4) application rates. Error bars represent standard deviation of effluent TN between triplicate columns for treatment. Letters signify statistically significant difference between treatments. Note: Entire bar (with no fill) represents total influent TN, where entire solid bar represents TN in effluent. Individual N species in the effluent are denoted based on color (blue, red, green).
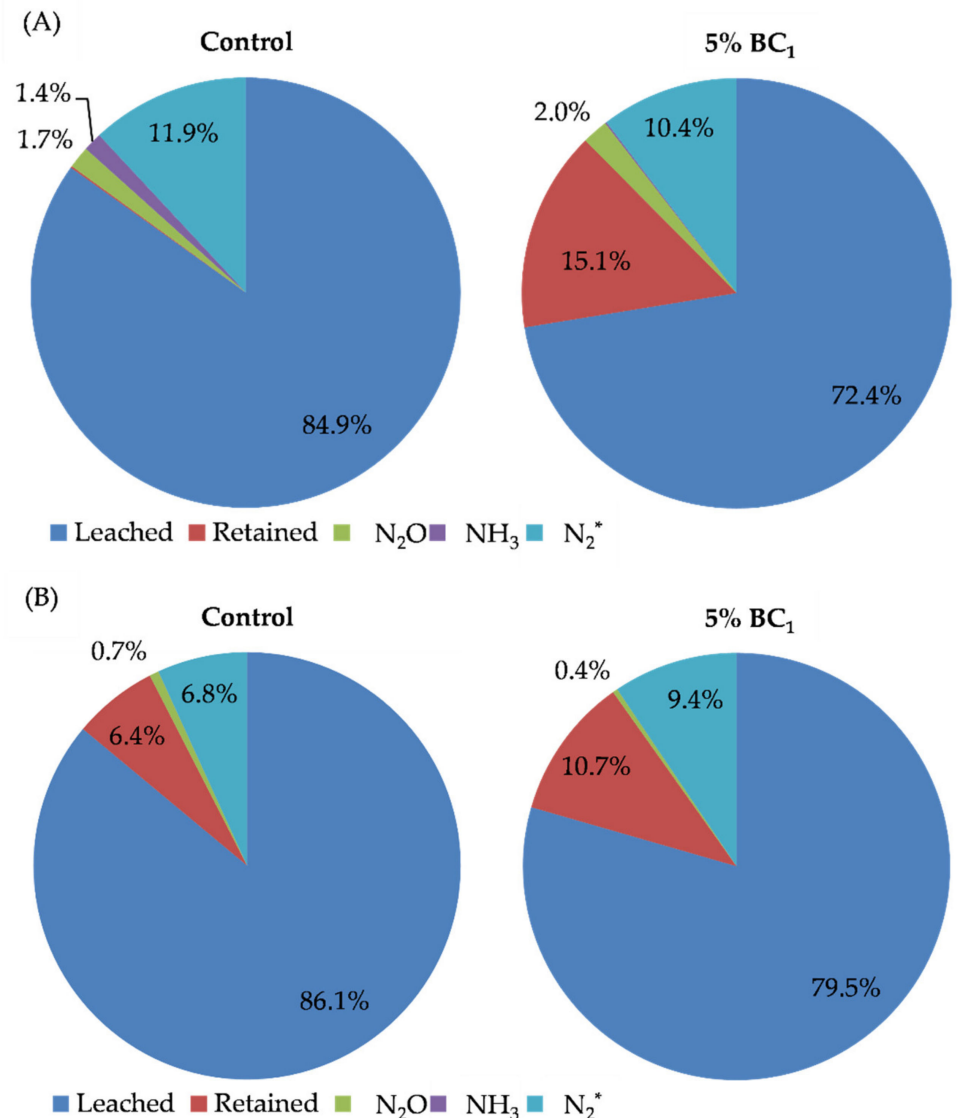

Figure 4. Nitrogen mass balance for influent $\mathrm{N}$ for columns receiving (A) $\mathrm{NH}_{4}{ }^{+}-\mathrm{N}$ low (treatment group (3) and (B) $\mathrm{NH}_{4}{ }^{+}-\mathrm{N}$ high (treatment group (4) application rates. * Assumed that influent TN unaccounted for in effluent $\mathrm{N}$, retention $\mathrm{N}, \mathrm{N}_{2} \mathrm{O}$, or $\mathrm{NH}_{3}$ was assumed to be lost as $\mathrm{N}_{2}$. 


\subsection{Nitrate Application (Treament Group 5)}

For columns receiving weekly applications of $\mathrm{NO}_{3}{ }^{-}-\mathrm{N}$ (treatment group 5 ), $\mathrm{BC}_{2}$ and $\mathrm{BC}_{3}$ reduced the $\mathrm{NO}_{3}{ }^{-}-\mathrm{N}$ leaching by $24.8 \%$ and $8.8 \%$ compared to the control column, respectively. There was no significant difference between control and $\mathrm{BC}_{1}$ (Figure 5A). The soil $\mathrm{NO}_{3}{ }^{-}-\mathrm{N}$ concentrations significantly increased for $\mathrm{BC}_{2}$ compared to other treatments (Table 2), and the mass retained accounted for the entire difference between $\mathrm{N}$ leached through $\mathrm{BC}_{2}$ verses the influent. For $\mathrm{BC}_{2}, 7.9 \%$ of the total influent $\mathrm{N}$ applied was lost as $\mathrm{N}$ emission other than $\mathrm{NH}_{3}$ and $\mathrm{N}_{2} \mathrm{O}$. All biochar treatments significantly reduced $\mathrm{N}_{2} \mathrm{O}$ emissions compared to control columns, but there was no significant difference between biochar treatments (Figure 5B).

(A)

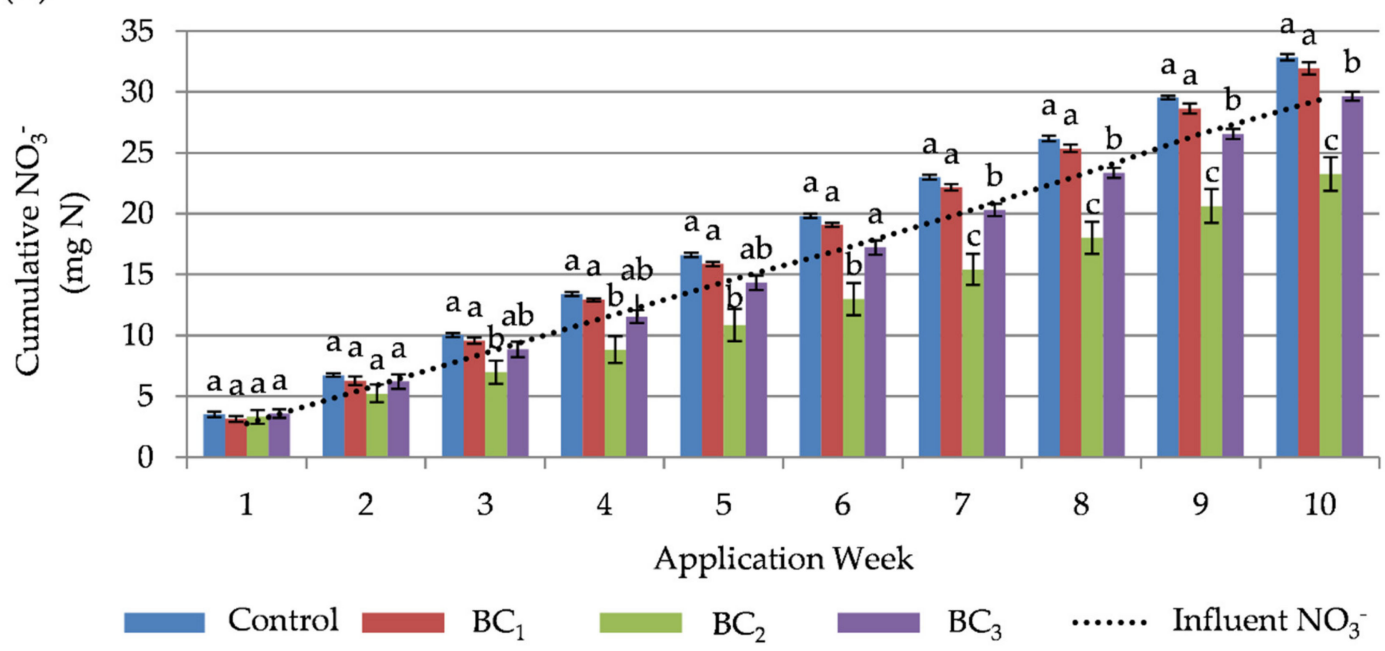

(B)

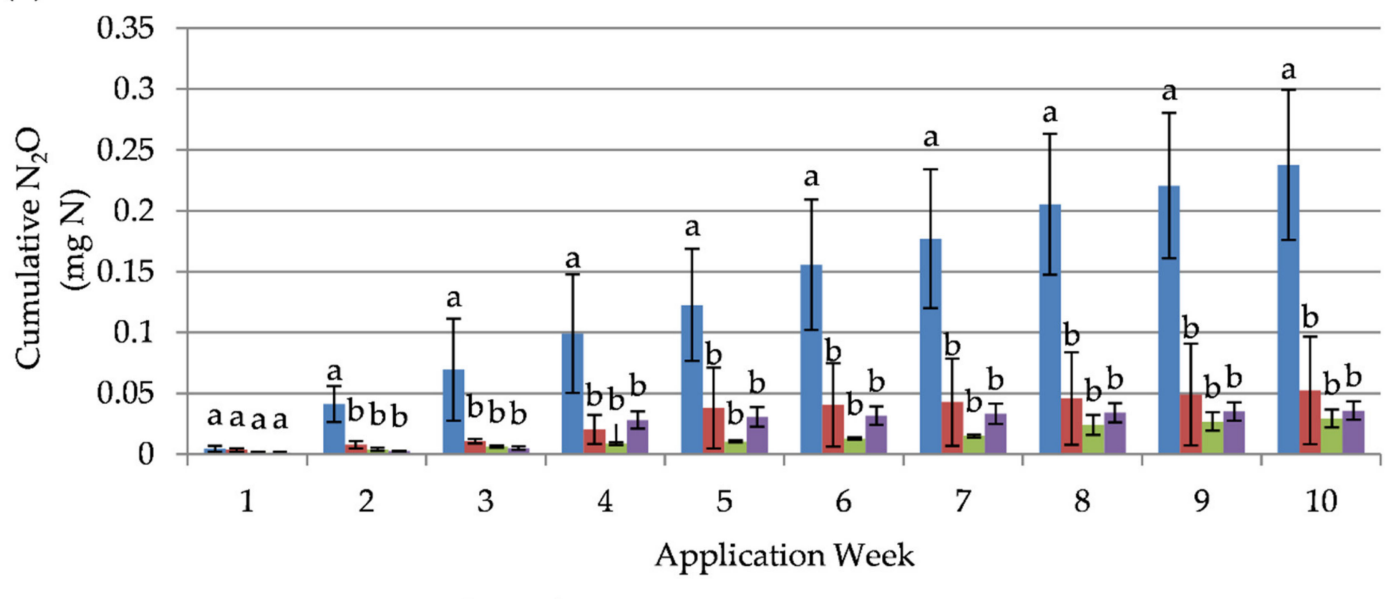

" Control $\| \mathrm{BC}_{1} \quad \square \mathrm{BC}_{2} \quad \square \mathrm{BC}_{3}$

Figure 5. Cumulative (A) $\mathrm{NO}_{3}{ }^{-}-\mathrm{N}$ leached and (B) $\mathrm{N}_{2} \mathrm{O}$ emitted from columns receiving $\mathrm{NO}_{3}{ }^{-}-\mathrm{N}$ applications. Different letters signify significant difference $(p<0.05)$ between control and biochar treatments. Error bars represent standard deviation between treatment triplicates.

\subsection{Changes in Biochar Characteristics}

The FTIR spectra measured an increase in oxygenated functional groups on the biochar surface following applications of all $\mathrm{N}$ forms (Figure 6). The small shoulder present in all spectra between 3500 and $3200 \mathrm{~cm}^{-1}$ is indicative of hydroxyl bands (-OH) associated with carboxylic acids, alcohols or phenols [29,59-61]. Peaks at $2850 \mathrm{~cm}^{-1}$ is indicative of addition of methoxyl $\left(\mathrm{O}-\mathrm{CH}_{3}\right)$ to biochar. Carboxylic groups are represented by 2850,1712 , and $1437 \mathrm{~cm}^{-1}[60,62]$. Carbonates are represented 
at 1436 and $875 \mathrm{~cm}^{-1}$ [63]. Carbonyl groups $(\mathrm{C}=\mathrm{O})$ are represented at 2150 and $1580 \mathrm{~cm}^{-1}[59,61]$. Increase in phenolic groups are represented by peak increases at 1262 and $1380 \mathrm{~cm}^{-1}$ [62]. Small peaks at 2165 and $1384 \mathrm{~cm}^{-1}$ indicate $\mathrm{N}$ on the biochar. A small peak for triple bonded $\mathrm{N}$ at $2165 \mathrm{~cm}^{-1}$ is observed [64]. Nitrite bound to the biochar can be observed at $1384 \mathrm{~cm}^{-1}$ [64-66].
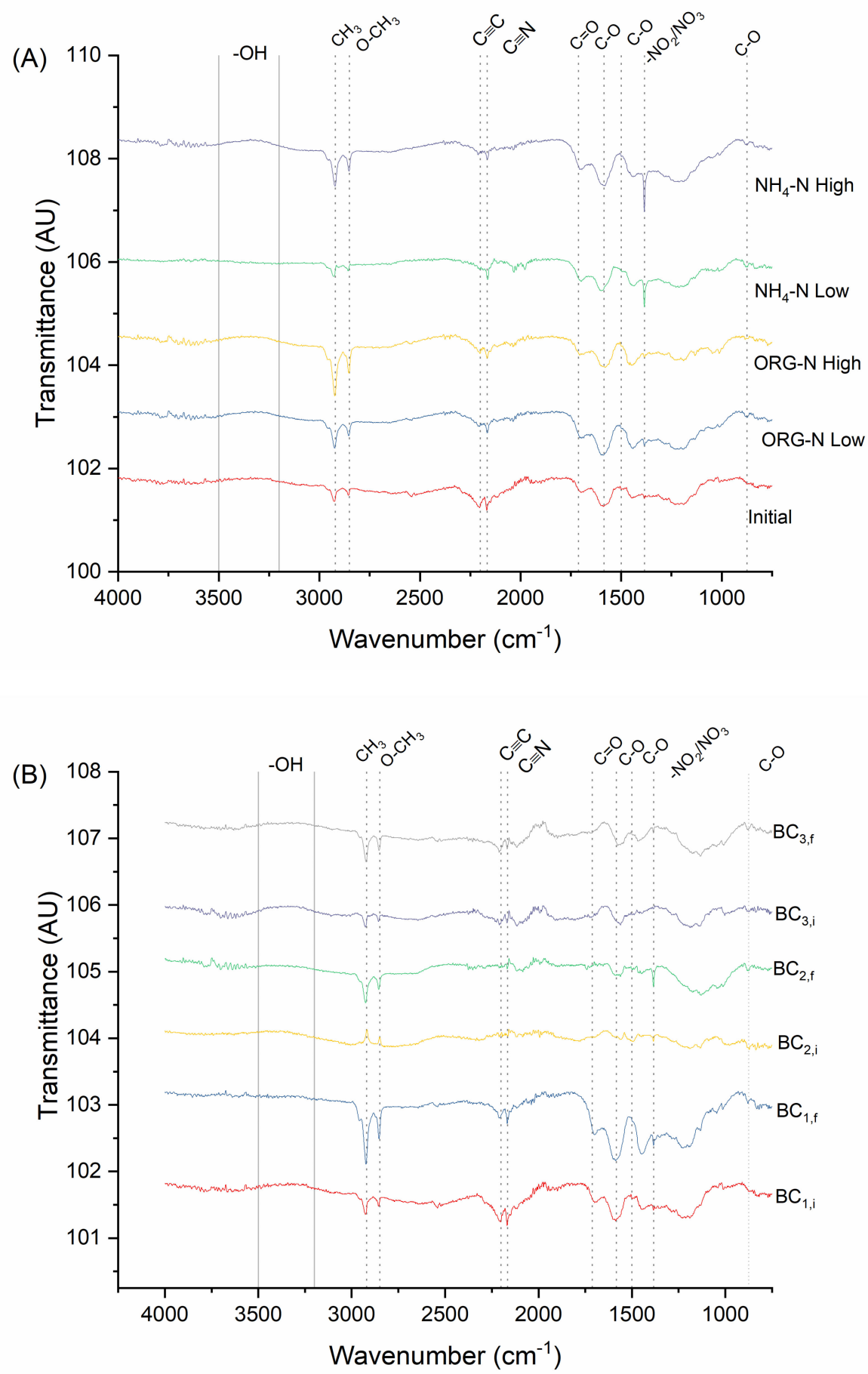

Figure 6. Fourier-transform infrared spectroscopy (FTIR) spectra of (A) $B_{1}$ initial and final for treatments 1 through 4 , and $(\mathbf{B}) \mathrm{BC}_{1}, \mathrm{BC}_{2}$, and $\mathrm{BC}_{3}$ initial and final for treatment group 5 .

The XPS data confirmed chemical changes to biochar following soil amendment and application of $\mathrm{N}$ solutions. High resolution $\mathrm{C} 1 \mathrm{~s}$ scan found a decrease in $\mathrm{C}-\mathrm{C}$ and $\mathrm{C}-\mathrm{H}$ bounds and an increase in oxygenated functional groups (Table 3 and Table S3). Oxygen content was roughly 1.5 times higher for 
all treatments following soil amendment. Additionally, other major elements including aluminum $(\mathrm{Al})$, calcium $(\mathrm{Ca})$, iron (Fe), magnesium $(\mathrm{Mg})$, silicon (Si), and tin (Sn) were detected on the biochar surface following soil amendment.

Table 3. X-ray photo-electron spectroscopy (XPS) scan of major elements and functional groups on the surface of $\mathrm{BC}_{1}$ before and after soil amendment for columns receiving ORG-N and $\mathrm{NH}_{4}{ }^{+}-\mathrm{N}$ low and high application rates. Value is mean (standard deviation) from triplicate columns. Significant difference $(p=0.05)$ between $\mathrm{BC}_{1}$ initial and $\mathrm{BC}_{1}$ final for treatments one through four are denoted with an asterisk $\left(^{*}\right)$. Elemental peaks that were not detected are signified by n.d.

\begin{tabular}{|c|c|c|c|c|c|}
\hline \multirow[b]{2}{*}{ Element } & \multicolumn{5}{|c|}{ Atomic Composition (\%) } \\
\hline & $\mathrm{BC}_{1}$ Initial & $\begin{array}{c}\text { BC }_{1} \text { after } \\
\text { ORG-N Low } \\
\text { Application } \\
\text { (Treatment } \\
\text { Group 1) }\end{array}$ & $\begin{array}{l}\text { BC }_{1} \text { after } \\
\text { ORG-N High } \\
\text { Application } \\
\text { (Treatment } \\
\text { Group 2) }\end{array}$ & $\begin{array}{c}\mathrm{BC}_{1} \text { after } \\
\mathrm{NH}_{4}^{+}-\mathrm{N} \text { Low } \\
\text { Application } \\
\text { (Treatment } \\
\text { Group 3) }\end{array}$ & $\begin{array}{c}\mathrm{BC}_{1} \text { after } \\
\mathrm{NH}_{4}^{+}-\mathrm{N} \text { High } \\
\text { Application } \\
\text { (Treatment } \\
\text { Group 4) }\end{array}$ \\
\hline $\mathrm{C}$ & $84.79(1.53)$ & $68.13(1.79) *$ & $69.65(2.17) *$ & $72.17(2.79) *$ & $71.12(3.03) *$ \\
\hline $\mathrm{C}-\mathrm{C} / \mathrm{C}-\mathrm{H}$ & $67.25(0.72)$ & $48.83(0.49) *$ & $47.90(2.19) *$ & $49.63(3.27) *$ & $48.03(2.70) *$ \\
\hline $\mathrm{C}-\mathrm{O} / \mathrm{C}-\mathrm{OC}$ & $9.38(0.43)$ & $10.19(0.66)$ & $11.44(0.78) *$ & $10.88(0.65) *$ & $11.58(0.93)$ * \\
\hline $\mathrm{C}=\mathrm{O}$ & $3.63(0.22)$ & $4.10(0.27)$ & $4.70(0.50) *$ & $4.45(0.30) *$ & $5.39(0.79) *$ \\
\hline$O=C-C$ & $2.24(0.15)$ & $2.80(0.70)$ & $3.41(0.27)$ * & $3.46(0.62)$ * & $2.91(0.54) *$ \\
\hline Shake up & $1.44(0.36)$ & $1.28(0.52)$ & $1.04(0.31)$ & $2.53(0.79)$ & $2.01(0.14)$ \\
\hline Quinone & $0.86(0.07)$ & $0.94(0.07)$ & $1.16(0.25)$ & $1.21(0.35)$ & $1.19(0.30)$ \\
\hline $\mathrm{O}$ & $13.49(0.73)$ & $20.89(0.29)$ * & $20.95(1.60) *$ & $19.10(1.82) *$ & $19.96(1.62) *$ \\
\hline $\mathrm{N}$ & $1.21(0.04)$ & $1.70(0.37) *$ & $3.15(0.25)$ * & $1.66(0.28) *$ & $1.86(0.11)^{*}$ \\
\hline $\mathrm{P}$ & n.d. & $0.88(0.19) *$ & $1.26(0.24)$ * & $0.21(0.07)$ * & $0.42(0.03)$ * \\
\hline $\mathrm{Al}$ & n.d. & $2.11(0.35) *$ & $0.99(0.08)$ * & $1.74(0.29)$ * & $1.51(0.06) *$ \\
\hline $\mathrm{Ca}$ & n.d. & $0.63(0.12) *$ & $0.65(0.07)$ * & $0.57(0.03)$ * & $0.66(0.04) *$ \\
\hline $\mathrm{Cl}$ & n.d. & n.d. & n.d. & $0.14(0.04)$ * & $0.32(0.12)$ * \\
\hline $\mathrm{Fe}$ & n.d. & $0.62(0.20) *$ & $0.65(0.11)$ * & $0.40(0.07)$ * & $0.12(0.01) *$ \\
\hline $\mathrm{Mg}$ & $0.11(0.01)$ & $0.41(0.04)$ * & $0.27(0.05)$ * & $0.37(0.03)$ * & $0.51(0.11)$ * \\
\hline $\mathrm{Si}$ & $0.40(0.01)$ & $4.31(0.74) *$ & $2.09(0.20)$ * & $3.35(0.86)$ * & $3.18(1.13)$ * \\
\hline Sn & n.d. & $0.32(0.03)$ * & $0.35(0.05)$ * & $0.30(0.06)$ * & $0.33(0.07)$ * \\
\hline
\end{tabular}

\section{Discussion}

Biochar application $\left(\mathrm{BC}_{1}\right)$ had a significant reduction on $\mathrm{N}$ leaching for all treatments compared to the control, except for the ORG-N high (treatment group 2) and $\mathrm{NO}_{3}{ }^{-}-\mathrm{N}$ application. For $\mathrm{BC}_{1}$ amended columns with ORG- N low application (treatment group 1) TN leaching was reduced by $18.7 \%$ compared to control columns. Almost all effluent (greater than 95\%) was in the form of $\mathrm{NO}_{3}{ }^{-}-\mathrm{N}^{-}$ resulting in $58.7 \%$ and $47.3 \%$ of the influent $\mathrm{TN}$ leaching through the control and $\mathrm{BC}_{1}$ columns as $\mathrm{NO}_{3}{ }^{-}-\mathrm{N}$, respectively, suggesting that a majority of the influent $\mathrm{N}$ underwent mineralization and/or nitrification. Similarly, in Xu et al. [9], where urea was applied at $250 \mathrm{~kg} \mathrm{~N}^{-1}$ to soil amended with biochar made from corn straw, the cumulative TN leaching was reduced up to $20 \%$ by biochar amended soils compared to controls, and more than $90 \%$ of the effluent was in the form of $\mathrm{NO}_{3}{ }^{-}-\mathrm{N}^{-}$ At lower application rates of ORG-N, biochar is able to reduce the $\mathrm{NO}_{3}{ }^{-}-\mathrm{N}$ lost as leachate. Weekly $\mathrm{TN}$ reduction efficiency averaged $17 \pm 5 \%$ through the ten weeks where removal performance did not change over time. This suggests that low-temperature biochar amendment could effectively be implemented into agricultural treatment systems receiving regular application doses of ORG-N, similar to silage bunker pad runoff, to reduce $\mathrm{N}$ leaching to groundwater sources. When higher ORG-N applications were applied almost all of the leached $\mathrm{N}$ remained in the form of ORG-N, where $71.0 \%$ and $68.2 \%$ of the influent from control and biochar columns was lost as ORG-N in the effluent. In past manure leaching studies reductions in $\mathrm{TN}$ leaching up to $60 \%$ were measured with additions of biochar [11,12]. In this study, the applications of $\mathrm{N}$ at manure concentrations were applied repeatedly, resulting in much higher $\mathrm{N}$ applications than other studies. It is hypothesized that this likely reduced 
the mineralization to inorganic $\mathrm{N}$ forms due to an imbalance of the $\mathrm{C}$ to $\mathrm{N}$ ratio as no additional $\mathrm{C}$ sources were applied. This may also suggests that the $\mathrm{C}$ added via biochar is not bioavailable in the soil in this timeframe.

At lower $\mathrm{NH}_{4}{ }^{+}-\mathrm{N}$ application concentrations (treatment group 3) TN leaching was reduced by $14.6 \%$ for biochar amended columns compared to control columns. As with the ORG-N applications, a majority of the leachate was in the form of $\mathrm{NO}_{3}{ }^{-}-\mathrm{N}(99 \%)$, suggesting a majority of the influent $\mathrm{N}$ underwent nitrification. Weekly repeated applications of $\mathrm{NH}_{4}{ }^{+}-\mathrm{N}$ were consistent in $\mathrm{TN}$ retention similar to the ORG-N column, where the $\mathrm{NH}_{4}{ }^{+}-\mathrm{N}$ low columns averaged a $13 \pm 5 \%$ reduction of TN leaching from the control over the ten weeks of application. For $\mathrm{NH}_{4}{ }^{+}-\mathrm{N}$ high application rate (treatment group 4), TN leaching was significantly reduced by $8 \%$ when biochar was amended to the soil. Unlike the lower application rate, the effluent was a mix of both $\mathrm{NH}_{4}{ }^{+}-\mathrm{N}(84 \%-87 \%)$ and $\mathrm{NO}_{3}{ }^{-}-\mathrm{N}$ $(13 \%-15 \%)$, which could be due to the imbalance of $\mathrm{C}$ to $\mathrm{N}$ in the soil. Other studies that have applied synthetic $\mathrm{NH}_{4}{ }^{+}-\mathrm{N}$ fertilizers to biochar amended soils at high application rates have found $\mathrm{NH}_{4}{ }^{+}-\mathrm{N}$ to make up a majority of the effluent TN [67].

In the columns receiving ORG-N and $\mathrm{NH}_{4}{ }^{+}-\mathrm{N}$ applications (treatment groups 1 through 4), soil $\mathrm{N}$ retention is the primary mechanism for reducing $\mathrm{N}$ leaching in biochar amended soils. In all cases where $\mathrm{N}$ leaching was significantly reduced, the change in TN retained in the soil was significantly higher for those amended with $\mathrm{BC}_{1}$. Many studies have theorized that biochar primarily retains $\mathrm{N}$ though binding of $\mathrm{NH}_{4}{ }^{+}$due to the increased CEC content $[28,68]$. However, in this study there was no significant difference in soil $\mathrm{NH}_{4}{ }^{+}-\mathrm{N}$ content between biochar and control columns for any of the applications. Similar results have been observed in field studies performing soil extractions following amendment, which have found that $\mathrm{NO}_{3}{ }^{-}-\mathrm{N}$ was more abundant than $\mathrm{NH}_{4}{ }^{+}-\mathrm{N}[16,18-20,29,30]$. While there was a significant increase in soil $\mathrm{NO}_{3}{ }^{-}-\mathrm{N}$ between treatments when $\mathrm{N}$ leaching was reduced, the binding of $\mathrm{NO}_{3}{ }^{-}-\mathrm{N}$ in the soil did not account for the majority of the difference in leached $\mathrm{N}$ between control and biochar columns. The retention of ORG-N within the columns accounted for most of the difference in the $\mathrm{N}$ leaching suggesting it is the primary mechanism for leaching reduction. For columns receiving low ORG-N applications (treatment group 1), the $\mathrm{BC}_{1}$ amended columns had a significantly higher change in soil ORG-N following applications, which accounted for most of the difference in $\mathrm{N}$ leaching between control and biochar columns. For the columns receiving $\mathrm{NH}_{4}{ }^{+}-\mathrm{N}$ applications (treatment groups 3 and 4), $\mathrm{NO}_{3}{ }^{-}-\mathrm{N}$ binding played the major role in retaining $\mathrm{N}$ within the column, but the biochar columns also retained more of the ORG-N originally in the soil. Thus, biochar may have inhibited some of the soils original ORG-N from undergoing mineralization.

Biochar increased retention of $\mathrm{NO}_{3}{ }^{-}-\mathrm{N}$ in the all columns receiving ORG-N and $\mathrm{NH}_{4}{ }^{+}-\mathrm{N}$ applications even though biochar has been reported to have a low sorption capacity for $\mathrm{NO}_{3}{ }^{-}-\mathrm{N}[31,34]$. Biochar is known to undergo changes when aged in soil or composted $[29,30]$. Biochar properties, such as oxidation, are altered following amendment to soil that results in $\mathrm{NO}_{3}{ }^{-}-\mathrm{N}$ binding. The FTIR spectra in this study measured an increase in peaks related to oxygenated functional groups (Figure 6). The XPS data also measured an increase in oxygenated functional groups on the biochar surface and an increase in positively-charged minerals (particularly $\mathrm{Al}, \mathrm{Ca}, \mathrm{Fe}, \mathrm{Mg}, \mathrm{Si}$, and $\mathrm{Sn}$ ) bound to the biochar surface (Table 2). The increase in minerals and oxygenated functional groups may have resulted in cationic bridging between $\mathrm{NO}_{3}{ }^{-}-\mathrm{N}$ and biochar, as previously suggested [36]. However, changes in oxygenated functional groups and minerals were similar to results observed in Joseph et al. [29], which concluded that the formation of an organomineral layer on biochar surface resulted in the uptake of $\mathrm{NO}_{3}{ }^{-}-\mathrm{N}$. In that study, the formation of the organomineral layer occurred on biochar that underwent composting after six weeks, thus it is plausible that the formation of organomineral layer in this ten-week study could have occurred. It is likely that both these processes are contributing to the increase in $\mathrm{NO}_{3}{ }^{-}-\mathrm{N}$ retention.

The enhanced retention of ORG-N within the soil columns amended with biochar may be the result of similar mechanisms of $\mathrm{NO}_{3}{ }^{-}$-N. Sorption of ORG-N to biochar has not been studied extensively, but studies have identified biochar as being able to bind dissolved organic $\mathrm{C}$. Chun et al. [62] observed 
that biochar could adsorb organic contaminates and linked the uptake to surface functional groups present on the biochar, with higher content of carboxyl groups increasing uptake. Güereña et al. [17] observed biochar amended soil in a field study had higher dissolved ORG-N content and suggested that the same surface functional mechanism that bound organic contaminates in Chun et al. [62] likely increase biochar uptake of ORG-N.

The reduction in $\mathrm{N}$ leaching following applications similar to silage bunker runoff are promising for future implementation into treatment systems. These systems have been reported to result in high leachate concentrations of $\mathrm{NO}_{3}{ }^{-}[44,45]$, thus a $16.5 \%$ (treatment group 1) or $14.6 \%$ (treatment group 3) reduction could have a significant impact on $\mathrm{NO}_{3}{ }^{-}$leaching through treatment systems. However, it is important to note that this study was conducted in a laboratory setting, thus conditions were different than actual field conditions. Climate, soil texture, and influent runoff all could have impacts on treatment performance in the field, thus future studies should further evaluate biochar amendment to these treatment systems receiving $\mathrm{N}$-rich silage bunker runoff.

Based on the findings from the ORG-N and $\mathrm{NH}_{4}{ }^{+}-\mathrm{N}$ application columns it would be expected that biochar would reduce $\mathrm{N}$ leaching when receiving $\mathrm{NO}_{3}{ }^{-}-\mathrm{N}$. However, $\mathrm{BC}_{1}$ did not significantly reduce leaching compared to control as it did in the other trials. A potential explanation may be due to retention time required for $\mathrm{NO}_{3}{ }^{-}-\mathrm{N}$ binding to biochar exchange sites. Past studies have indicated that significant retention time ( $>1 \mathrm{hr})$ is required to bind $\mathrm{NO}_{3}{ }^{-}-\mathrm{N}$ to oxidized biochar [36]. In the ORG-N and $\mathrm{NH}_{4}{ }^{+}-\mathrm{N}$ columns it is likely that the soils natural exchange sites retained a portion of influent ORG-N and $\mathrm{NH}_{4}{ }^{+}-\mathrm{N}$, and between application events $\mathrm{N}$ underwent mineralization and nitrification. Therefore, between applications the $\mathrm{NO}_{3}{ }^{-}-\mathrm{N}$ had sufficient time to bind to the biochar exchange sites. When comparing the difference between control and biochar amended columns by week, none of the columns resulted in significant difference in $\mathrm{NO}_{3}{ }^{-}-\mathrm{N}$ leaching between treatments until week two (Figure S1), supporting this theory. However, in the $\mathrm{NO}_{3}{ }^{-}-\mathrm{N}$ application events, because $\mathrm{NO}_{3}{ }^{-}-\mathrm{N}$ is known to be highly mobile in soil, it is possible that the $\mathrm{NO}_{3}{ }^{-}-\mathrm{N}$ was flushed out during application, resulting in little $\mathrm{N}$ remaining to undergo binding between application events. However, higher temperature produced biochar, $\mathrm{BC}_{2}$, did result in a significant reduction in $\mathrm{N}$ leaching by $24.8 \%$ compared to control. Other studies have found that biochar produced at high temperatures can bind $\mathrm{NO}_{3}{ }^{-}-\mathrm{N}$ due to the higher surface area of the biochar [34]. However, other studies have suggested enhancement of functional groups may result in greater binding of high temperature biochar [6,31]. The XPS data measured a greater abundance of oxygenated functional groups of higher temperature biochar (Table S3), which is likely to have increased sorption of $\mathrm{NO}_{3}{ }^{-}-\mathrm{N}$ in $\mathrm{BC}_{2}$ columns. To enhance retention of $\mathrm{NO}_{3}{ }^{-}-\mathrm{N}$, it was hypothesized that pre-oxidized biochar $\left(\mathrm{BC}_{3}\right)$ would result in a higher retention [36]. However, similar to Mia et al. [67], $\mathrm{BC}_{3}$ did not result did not significantly enhance the soil retention of $\mathrm{NO}_{3}{ }^{-}-\mathrm{N}$, suggesting that chemical oxidation prior to soil amendment may not be a substitute to chemical change occurring in the soil, or the dominant process may be the development of an organomineral layer.

There were no significant differences in measured $\mathrm{N}$ emissions from columns, with the exception of the $\mathrm{NO}_{3}{ }^{-}-\mathrm{N}$ application, which resulted in lower $\mathrm{N}_{2} \mathrm{O}$ emissions from soil columns amended with biochar (Figure $5 \mathrm{~B}$ ). This suggest that biochar may aid in mitigating greenhouse gas emissions from agricultural treatment systems. Since $\mathrm{BC}_{1}$ biochar did not result in significant soil retention of $\mathrm{NO}_{3}{ }^{-}-\mathrm{N}$ but did reduce $\mathrm{N}_{2} \mathrm{O}$ emissions, it is likely that immobilization of $\mathrm{NO}_{3}{ }^{-}-\mathrm{N}$ is not the primary mechanisms for emission reductions. Emissions of $\mathrm{N}_{2} \mathrm{O}$ are correlated to $\mathrm{pH}$, and biochar may have resulted in buffering the soil to reduce the production of $\mathrm{N}_{2} \mathrm{O}$. However, soil $\mathrm{pH}$ was not significantly different with biochar amendment in this study (Table S4). Biochar may have impacted microbial communities as suggested in past studies which found increases in microbial gene abundance of nosZ with biochar amendment $[13,14]$. 


\section{Conclusions}

Amendment of biochar to a sandy loam soil significantly reduced the leaching of $\mathrm{N}$ when receiving repeated applications with $\mathrm{N}$ concentrations similar to farmstead runoff. Soil analysis indicated that biochar impacted $\mathrm{N}$ leaching through enhanced soil retention of both ORG-N and $\mathrm{NO}_{3}{ }^{-}-\mathrm{N}$. Surface chemistry analysis indicated that biochar, following soil amendment, had an increase in oxygenated functional groups and cationic minerals on the biochar surface increasing soil retention of ORG-N and $\mathrm{NO}_{3}{ }^{-}-\mathrm{N}$ through cationic bridging or the development of an organomineral layer on the biochar surface. The repeated application of $\mathrm{N}$ over the course of ten weeks did not impact biochar $\mathrm{N}$ leaching reduction performance, although it is likely that a maximum reduction potential would be reached. However, to effectively reduce $\mathrm{N}$ leaching from direct application of $\mathrm{NO}_{3}{ }^{-} \mathrm{N}$, only high temperature production biochars at $700{ }^{\circ} \mathrm{C}$ resulted in a significant reduction in $\mathrm{N}$ leaching of $24.8 \%$. However, it is important to note that this was a short-term laboratory study, which varies greatly from field conditions. Thus, before widespread implementation, future fields studies are necessary to confirm performance under field conditions. Natural oxidation and development of organomineral layers were more effective in retaining applied $\mathrm{NO}_{3}{ }^{-} \mathrm{N}$ than those oxidized prior to soil amendment, which may indicate organomineral layer development may be more important or natural oxidation processes are more effective at developing conditions that can bind $\mathrm{NO}_{3}{ }^{-}-\mathrm{N}$, but more investigation is needed to assess this.

Supplementary Materials: The following are available online at http://www.mdpi.com/2073-4395/10/7/979/s1, Table S1: Biochar production temperature, treatments, elemental content, and $\mathrm{pH}$; Table S2: Water quality analysis parameters, EPA approved method, and detection limits; Table S3: XPS scan of major elements and carbon functional groups on the surface of biochar before and after soil amendment for columns receiving NO3-N low and high application rates; Figure S1: Weekly cumulative $\mathrm{NO}_{3}{ }^{-}$-N effluent for (A) ORG-N low, (B) $\mathrm{NH}_{4}{ }^{+}-\mathrm{N}$ low, and (C) $\mathrm{NH}_{4}{ }^{+}-\mathrm{N}$ high application; Table S4: Soil $\mathrm{pH}$ following application for treatments.

Author Contributions: J.R.S. contributed to the methodology, conceptualization, laboratory analysis, completed the formal analysis and writing of the original draft preparation. R.A.L. contributed to the conceptualization, methodology, writing-review and editing, supervision, project administration, and funding acquisition. All authors have read and agreed to the published version of the manuscript.

Funding: This material is based upon work that is supported by the National Institute of Food and Agriculture, U.S. Department of Agriculture under project numbers 2015-67019-23573 and 2017-67003-26055. Any opinions, findings, conclusions, or recommendations expressed in this publication are those of the author(s) and do not necessarily reflect the view of the U.S. Department of Agriculture.

Acknowledgments: The author gratefully acknowledges the use of facilities and instruments supported by NSF [DMR-1720415] through the University of Wisconsin-Madison Materials Research Science and Engineering Center.

Conflicts of Interest: The authors declare no conflict of interest.

\section{References}

1. Chia, C.; Downie, A.; Munroe, P. Characteristics of biochar: Physical and structural properties. In Biochar for Environmental Management: Science, Technology, and Implementation; Lehmann, J., Joseph, S., Eds.; Routledge: New York, NY, USA, 2015; pp. 89-109.

2. Ippolito, J.A.; Spoka, K.A.; Novak, J.M.; Lentz, R.D.; Cantrell, K.B. Biochar elemental composition and factors influencing nutrient retention. In Biochar for Environmental Management: Science, Technology, and Implementation; Lehmann, J., Joseph, S., Eds.; Routledge: New York, NY, USA, 2015; pp. 139-163.

3. Lehmann, J.; Joseph, S. Biochar for environmental management: An introduction. In Biochar for Environmental Management: Science, Technology, and Implementation; Lehmann, J., Joseph, S., Eds.; Routledge: New York, NY, USA, 2015; pp. 1-14.

4. Ahmed, R.; Li, Y.; Mao, L.; Xu, C.; Lin, W.; Ahmed, S.; Ahmed, W. Biochar Effects on Mineral Nitrogen Leaching, Moisture Content, and Evapotranspiration after 15N Urea Fertilization for Vegetable Crop. Agronomy 2019, 9, 331. [CrossRef]

5. Ding, Y.; Liu, Y.-X.; Wu, W.; Shi, D.; Yang, M.; Zhong, Z.-K. Evaluation of Biochar Effects on Nitrogen Retention and Leaching in Multi-Layered Soil Columns. Water Air Soil Pollut. 2010, 213, 47-55. [CrossRef] 
6. Kameyama, K.; Miyamoto, T.; Shiono, T.; Shinogi, Y. Influence of Sugarcane Bagasse-derived Biochar Application on Nitrate Leaching in Calcaric Dark Red Soil. J. Environ. Qual. 2012, 41, 1131-1137. [CrossRef] [PubMed]

7. Li, S.; Zhang, Y.; Yan, W.; Shangguan, Z. Effect of biochar application method on nitrogen leaching and hydraulic conductivity in a silty clay soil. Soil Tillage Res. 2018, 183, 100-108. [CrossRef]

8. Uzoma, K.C.; Inoue, M.; Andry, H.; Zahoor, A.; Nishihara, E. Influence of biochar application on sandy soil hydraulic properties and nutrient retention. J. Food Agric. Environ. 2011, 9, 1137-1143.

9. Xu, N.; Tan, G.; Wang, H.; Gai, X. Effect of biochar additions to soil on nitrogen leaching, microbial biomass and bacterial community structure. Eur. J. Soil Biol. 2016, 74, 1-8. [CrossRef]

10. Yao, Y.; Gao, B.; Zhang, M.; Inyang, M.; Zimmerman, A.R. Effect of biochar amendment on sorption and leaching of nitrate, ammonium, and phosphate in a sandy soil. Chemosphere 2012, 89, 1467-1471. [CrossRef]

11. Bradley, A.; Larson, R.A.; Runge, T. Effect of Wood Biochar in Manure-Applied Sand Columns on Leachate Quality. J. Environ. Qual. 2015, 44, 1720-1728. [CrossRef]

12. Laird, D.A.; Fleming, P.; Wang, B.; Horton, R.; Karlen, D. Biochar impact on nutrient leaching from a Midwestern agricultural soil. Geoderma 2010, 158, 436-442. [CrossRef]

13. Harter, J.; Krause, H.-M.; Schuettler, S.; Ruser, R.; Fromme, M.; Scholten, T.; Kappler, A.; Behrens, S. Linking $\mathrm{N} 2 \mathrm{O}$ emissions from biochar-amended soil to the structure and function of the N-cycling microbial community. ISME J. 2013, 8, 660-674. [CrossRef]

14. Harter, J.; Elhadidi, M.; Huson, D.H.; Kappler, A.; Behrens, S. Soil biochar amendment affects the diversity of nosZ transcripts: Implications for $\mathrm{N} 2 \mathrm{O}$ formation. Sci. Rep. 2017, 7, 3338. [CrossRef]

15. Bai, S.H.; Reverchon, F.; Xu, C.-Y.; Xu, Z.; Blumfield, T.; Zhao, H.-T.; Van Zwieten, L.; Wallace, H. Wood biochar increases nitrogen retention in field settings mainly through abiotic processes. Soil Biol. Biochem. 2015, 90, 232-240. [CrossRef]

16. Cayuela, M.L.; Sánchez-Monedero, M.A.; Roig, A.; Hanley, K.; Enders, A.; Lehmann, J. Biochar and denitrification in soils: When, how much and why does biochar reduce N2O emissions? Sci. Rep. 2013, 3, srep01732. [CrossRef]

17. Güereña, D.; Lehmann, J.; Hanley, K.; Enders, A.; Hyland, C.; Riha, S. Nitrogen dynamics following field application of biochar in a temperate North American maize-based production system. Plant Soil 2012, 365, 239-254. [CrossRef]

18. Martin, S.L.; Clarke, M.L.; Othman, M.; Ramsden, S.J.; West, H.M. Biochar-mediated reductions in greenhouse gas emissions from soil amended with anaerobic digestates. Biomass Bioenergy 2015, 79, 39-49. [CrossRef]

19. Sanford, J.; Larson, R.A. Treatment of horizontal silage bunker runoff using biochar amended vegetative filter strips. J. Environ. Manag. 2019, 253, 109746. [CrossRef]

20. Van Zwieten, L.; Kimber, S.; Morris, S.; Chan, K.Y.; Downie, A.; Rust, J.; Joseph, S.; Cowie, A. Effects of biochar from slow pyrolysis of papermill waste on agronomic performance and soil fertility. Plant Soil 2009, 327, 235-246. [CrossRef]

21. Yadav, V.; Karak, T.; Singh, S.; Singh, A.K.; Khare, P. Benefits of biochar over other organic amendments: Responses for plant productivity (Pelargonium graveolens L.) and nitrogen and phosphorus losses. Ind. Crop. Prod. 2019, 131, 96-105. [CrossRef]

22. Rashti, M.R.; Esfandbod, M.; Phillips, I.R.; Chen, C. Rhizosphere management by biochar and leaching improved plant performance in fresh bauxite residue sand. J. Clean. Prod. 2019, 219, 66-74. [CrossRef]

23. Lin, Y.; Munroe, P.; Joseph, S.; Henderson, R.K.; Ziolkowski, A. Water extractable organic carbon in untreated and chemical treated biochars. Chemosphere 2012, 87, 151-157. [CrossRef]

24. Nelissen, V.; Rütting, T.; Huygens, D.; Staelens, J.; Ruysschaert, G.; Boeckx, P. Maize biochars accelerate short-term soil nitrogen dynamics in a loamy sand soil. Soil Biol. Biochem. 2012, 55, 20-27. [CrossRef]

25. Hale, S.E.; Alling, V.; Martinsen, V.; Mulder, J.; Breedveld, G.D.; Cornélissen, G. The sorption and desorption of phosphate-P, ammonium-N and nitrate-N in cacao shell and corn cob biochars. Chemosphere 2013, 91, 1612-1619. [CrossRef]

26. Takaya, C.; Fletcher, L.; Singh, S.; Anyikude, K.; Ross, A. Phosphate and ammonium sorption capacity of biochar and hydrochar from different wastes. Chemosphere 2016, 145, 518-527. [CrossRef]

27. Wang, T.; Arbestain, M.C.; Hedley, M.; Bishop, P. Chemical and bioassay characterisation of nitrogen availability in biochar produced from dairy manure and biosolids. Org. Geochem. 2012, 51, 45-54. [CrossRef] 
28. Taghizadeh-Toosi, A.; Clough, T.J.; Sherlock, R.R.; Condron, L.M. Biochar adsorbed ammonia is bioavailable. Plant Soil 2011, 350, 57-69. [CrossRef]

29. Joseph, S.; Kammann, C.; Shepherd, J.; Conte, P.; Schmidt, H.-P.; Hagemann, N.; Rich, A.M.; Marjo, C.E.; Allen, J.; Munroe, P.; et al. Microstructural and associated chemical changes during the composting of a high temperature biochar: Mechanisms for nitrate, phosphate and other nutrient retention and release. Sci. Total. Environ. 2018, 618, 1210-1223. [CrossRef]

30. Kammann, C.; Schmidt, H.-P.; Messerschmidt, N.; Linsel, S.; Steffens, D.; Müller, C.; Koyro, H.-W.; Conte, P.; Joseph, S.; Stephen, J. Plant growth improvement mediated by nitrate capture in co-composted biochar. Sci. Rep. 2015, 5, 11080. [CrossRef] [PubMed]

31. Dempster, D.N.; Jones, D.L.; Murphy, D.V. Clay and biochar amendments decreased inorganic but not dissolved organic nitrogen leaching in soil. Soil Res. 2012, 50, 216-221. [CrossRef]

32. Hollister, C.C.; Bisogni, J.J.; Lehmann, J. Ammonium, Nitrate, and Phosphate Sorption to and Solute Leaching from Biochars Prepared from Corn Stover (Zea mays L.) and Oak Wood (Quercus spp.). J. Environ. Qual. 2013, 42, 137-144. [CrossRef]

33. Ohe, K.; Nagae, Y.; Nakamura, S.; Baba, Y. Removal of Nitrate Anion by Carbonaceous Materials Prepared from Bamboo and Coconut Shell. J. Chem. Eng. Jpn. 2003, 36, 511-515. [CrossRef]

34. Yang, J.; Li, H.; Zhang, D.; Wu, M.; Pan, B. Limited role of biochars in nitrogen fixation through nitrate adsorption. Sci. Total Environ. 2017, 592, 758-765. [CrossRef]

35. Haider, G.; Steffens, D.; Müller, C.; Kammann, C.I. Standard Extraction Methods May Underestimate Nitrate Stocks Captured by Field-Aged Biochar. J. Environ. Qual. 2016, 45, 1196-1204. [CrossRef] [PubMed]

36. Sanford, J.; Larson, R.A.; Runge, T. Nitrate sorption to biochar following chemical oxidation. Sci. Total Environ. 2019, 669, 938-947. [CrossRef] [PubMed]

37. Niu, Y.; Chen, Z.; Müller, C.; Zaman, M.M.; Kim, D.; Yu, H.; Ding, W. Yield-scaled N 2 O emissions were effectively reduced by biochar amendment of sandy loam soil under maize-Wheat rotation in the North China Plain. Atmos. Environ. 2017, 170, 58-70. [CrossRef]

38. Senbayram, M.; Saygan, E.P.; Chen, R.; Aydemir, S.; Kaya, C.; Wu, D.; Bladogatskaya, E. Effect of biochar origin and soil type on the greenhouse gas emission and the bacterial community structure in $\mathrm{N}$ fertilised acidic sandy and alkaline clay soil. Sci. Total Environ. 2019, 660, 69-79. [CrossRef]

39. Arnold, J.; Knapp, J.; Johnson, C. The use of yeasts to reduce the polluting potential of silage effluent. Water Res. 2000, 34, 3699-3708. [CrossRef]

40. Gebrehanna, M.; Gordon, R.J.; Madani, A.; Vanderzaag, A.; Wood, J.D. Silage effluent management: A review. J. Environ. Manag. 2014, 143, 113-122. [CrossRef] [PubMed]

41. Holly, M.A.; Larson, R.A.; Cooley, E.T.; Wunderlin, A.M. Silage storage runoff characterization: Annual nutrient loading rate and first flush analysis of bunker silos. Agric. Ecosyst. Environ. 2018, 264, 85-93. [CrossRef]

42. Bhattarai, R.; Kalita, P.K.; Patel, M.K. Nutrient transport through a Vegetative Filter Strip with subsurface drainage. J. Environ. Manag. 2009, 90, 1868-1876. [CrossRef]

43. Holly, M.A.; Larson, R.A. Treatment of Silage Runoff Using Vegetated Filter Strips. Trans. ASABE 2016, 59, 1645-1650. [CrossRef]

44. Faulkner, J.W.; Zhang, W.; Geohring, L.D.; Steenhuis, T.S. Nutrient transport within three vegetative treatment areas receiving silage bunker runoff. J. Environ. Manag. 2011, 92, 587-595. [CrossRef] [PubMed]

45. Larson, R.A.; Safferman, S.I. Field Application of Farmstead Runoff to Vegetated Filter Strips: Surface and Subsurface Water Quality Assessment. J. Environ. Qual. 2012, 41, 592-603. [CrossRef]

46. Bouyoucos, G.J. Hydrometer method improved for making particle size analysis of soils. Agron. J. 1962, 54, 464-465. [CrossRef]

47. Olk, D.; Fortuna, A.-M.; Honeycutt, C.W. Using Anion Chromatography-Pulsed Amperometry to Measure Amino Compounds in Dairy Manure-Amended Soils. Soil Sci. Soc. Am. J. 2008, 72, 1711-1720. [CrossRef]

48. King, K.; Williams, M.R.; Fausey, N. Effect of crop type and season on nutrient leaching to tile drainage under a corn-soybean rotation. J. Soil Water Conserv. 2016, 71, 56-68. [CrossRef]

49. Snoeyink, V.L.; Jenkins, D. Water Chemistry, 1st ed.; John Wiley \& Sons, Inc.: Hoboken, NJ, USA, 1980; ISBN 978-0471051961. 
50. Aneja, V.; Blunden, J.; Claiborn, C.; Rogers, H. Dynamic Chamber System to Measure Gaseous Compounds Emissions and Atmospheric-Biospheric Interactions. In Environmental Simulation Chambers: Application to Atmospheric Chemical Processes; Barnes, I., Rudzinski, K., Eds.; Springer: Dordrecht, The Netherlands, 2006; Volume 62, ISBN 978-1-4020-4230-0.

51. Parkin, T.B.; Venterea, R.T. USDA-ARS GRACEnet Project Protocols Chapter 3. Chamber-Based Trace Gas Flux Measurements. In Sampling Protocols; USDA: Washington, DC, USA, 2010; pp. 1-39.

52. Bremner, J.M. Inorganic Forms of Nitrogen. In Methods of Soil Analysis: Part 2 Chemical and Microbiological Properties; American Society of Agronomy, Inc.: Madison, WI, USA, 1965; pp. 1179-1237.

53. Ventura, M.; Sorrenti, G.; Panzacchi, P.; George, E.; Tonon, G. Biochar Reduces Short-Term Nitrate Leaching from A Horizon in an Apple Orchard. J. Environ. Qual. 2013, 42, 76-82. [CrossRef]

54. Hagemann, N.; Kammann, C.I.; Schmidt, H.-P.; Kappler, A.; Behrens, S. Nitrate capture and slow release in biochar amended compost and soil. PLoS ONE 2017, 12, e0171214. [CrossRef]

55. Walsh, J.; Sanford, J.; Larson, R.A. Evaluation of Biochar Nitrate Extraction Methods. Appl. Sci. 2019, 9, 3514. [CrossRef]

56. Bremner, J.M. Total Nitrogen. In Methods for Soil Analysis, Part 2; Norman, A.G., Ed.; American Society of Agronomy: Madison, WI, USA, 1965; pp. 1149-1178.

57. Cheng, C.-H.; Lehmann, J.; Thies, J.E.; Burton, S.D.; Engelhard, M. Oxidation of black carbon by biotic and abiotic processes. Org. Geochem. 2006, 37, 1477-1488. [CrossRef]

58. SAS Base. SAS®9.4 Procedures Guide: Statistical Procedures, 2nd ed.; SAS Institute Inc.: Cary, NC, USA, 2013.

59. Hina, K.; Bishop, P.; Arbestain, M.C.; Pereira, R.C.; Maciá-Agulló, J.A.; Hindmarsh, J.; Hanly, J.A.; Macias, F.; Hedley, M.J. Producing biochars with enhanced surface activity through alkaline pretreatment of feedstocks. Soil Res. 2010, 48, 606-617. [CrossRef]

60. Sharma, R.; Wooten, J.B.; Baliga, V.L.; Lin, X.; Chan, W.G.; Hajaligol, M.R. Characterization of chars from pyrolysis of lignin. Fuel 2004, 83, 1469-1482. [CrossRef]

61. Wang, S.; Wang, K.; Liu, Q.; Gu, Y.; Luo, Z.; Cen, K.; Fransson, T. Comparison of the pyrolysis behavior of lignins from different tree species. Biotechnol. Adv. 2009, 27, 562-567. [CrossRef]

62. Chun, Y.; Sheng, G.; Chiou, C.T.; Xing, B. Compositions and Sorptive Properties of Crop Residue-Derived Chars. Environ. Sci. Technol. 2004, 38, 4649-4655. [CrossRef] [PubMed]

63. Kloss, S.; Zehetner, F.; Dellantonio, A.; Hamid, R.; Ottner, F.; Liedtke, V.; Schwanninger, M.; Gerzabek, M.H.; Soja, G. Characterization of Slow Pyrolysis Biochars: Effects of Feedstocks and Pyrolysis Temperature on Biochar Properties. J. Environ. Qual. 2012, 41, 990-1000. [CrossRef]

64. Tang, X.; Liu, T.; Li, H.; Yang, D.; Chen, L.; Tang, X. Notably enhanced thermoelectric properties of lamellar polypyrrole by doping with-naphthalene sulfonic acid. RSC Adv. 2017, 7, 20192-20200. [CrossRef]

65. Wang, L.; Feng, S.; Zhao, J.; Zheng, J.; Wang, Z.; Li, L.; Zhu, Z. A facile method to modify carbon nanotubes with nitro/amino groups. Appl. Surf. Sci. 2010, 256, 6060-6064. [CrossRef]

66. Yang, L.; May, P.W.; Yin, L.; Smith, J.; Rosser, K.N. Ultra fine carbon nitride nanocrystals synthesized by laser ablation in liquid solution. J. Nanopart. Res. 2007, 9, 1181-1185. [CrossRef]

67. Mia, S.; Singh, B.; Dijkstra, F.A. Chemically oxidized biochar increases ammonium-15N recovery and phosphorus uptake in a grassland. Biol. Fertil. Soils 2019, 55, 577-588. [CrossRef]

68. Li, S.; Harris, S.; Anandhi, A.; Chen, G. Predicting biochar properties and functions based on feedstock and pyrolysis temperature: A review and data syntheses. J. Clean. Prod. 2019, 215, 890-902. [CrossRef]

(C) 2020 by the authors. Licensee MDPI, Basel, Switzerland. This article is an open access article distributed under the terms and conditions of the Creative Commons Attribution (CC BY) license (http://creativecommons.org/licenses/by/4.0/). 